\title{
An efficient nonviral gene-delivery vector based on hyperbranched cationic glycogen derivatives
}

This article was published in the following Dove Press journal:

International Journal of Nanomedicine

31 January 2014

Number of times this article has been viewed

\section{Xuan Liangl,* \\ Xianyue Ren ${ }^{2, *}$ \\ Zhenzhen Liu' \\ Yingliang Liu' \\ Jue Wang ${ }^{2}$ \\ Jingnan Wang ${ }^{2}$ \\ Li-Ming Zhang' \\ David YB Deng \\ Daping Quan' \\ Liqun Yang'}

'Institute of Polymer Science, School of Chemistry and Chemical Engineering, Key Laboratory of Designed Synthesis and Application of Polymer Material, Key Laboratory for Polymeric Composite and Functional Materials of Ministry of Education, Sun Yat-Sen University, Guangzhou, People's Republic of China; ${ }^{2}$ Research Center of Translational Medicine, The First Affiliated Hospital, Sun YatSen University, Guangzhou, People's Republic of China

*Both these authors contributed equally to this work

Correspondence: Liqun Yang School of Chemistry and Chemical Engineering, Sun Yat-Sen University, I 35 Xingang Xi Road, Guangzhou, Guangdong 510275,

People's Republic of China

Tel +8620 84II 0934

Email yanglq@mail.sysu.edu.cn

Correspondence: David YB Deng Research Center of Translational Medicine, The First Affiliated Hospital, Sun Yat-Sen University, Guangzhou 510080 , People's Republic of China Tel 87755766

Email dengyub@mail.sysu.edu.cn
Background: The purpose of this study was to synthesize and evaluate hyperbranched cationic glycogen derivatives as an efficient nonviral gene-delivery vector.

Methods: A series of hyperbranched cationic glycogen derivatives conjugated with 3-(dimethylamino)-1-propylamine (DMAPA-Glyp) and 1-(2-aminoethyl) piperazine (AEPZGlyp) residues were synthesized and characterized by Fourier-transform infrared and hydrogen-1 nuclear magnetic resonance spectroscopy. Their buffer capacity was assessed by acid-base titration in aqueous $\mathrm{NaCl}$ solution. Plasmid deoxyribonucleic acid (pDNA) condensation ability and protection against DNase I degradation of the glycogen derivatives were assessed using agarose gel electrophoresis. The zeta potentials and particle sizes of the glycogen derivative/ pDNA complexes were measured, and the images of the complexes were observed using atomic force microscopy. Blood compatibility and cytotoxicity were evaluated by hemolysis assay and MTT (3-[4,5-dimethylthiazol-2-yl]-2,5-diphenyltetrazolium bromide) assay, respectively. pDNA transfection efficiency mediated by the cationic glycogen derivatives was evaluated by flow cytometry and fluorescence microscopy in the 293T (human embryonic kidney) and the CNE2 (human nasopharyngeal carcinoma) cell lines. In vivo delivery of pDNA in model animals (Sprague Dawley rats) was evaluated to identify the safety and transfection efficiency.

Results: The hyperbranched cationic glycogen derivatives conjugated with DMAPA and AEPZ residues were synthesized. They exhibited better blood compatibility and lower cytotoxicity when compared to branched polyethyleneimine (bPEI). They were able to bind and condense pDNA to form the complexes of 100-250 $\mathrm{nm}$ in size. The transfection efficiency of the DMAPA-Glyp/pDNA complexes was higher than those of the AEPZ-Glyp/pDNA complexes in both the 293T and CNE2 cells, and almost equal to those of bPEI. Furthermore, pDNA could be more safely delivered to the blood vessels in brain tissue of Sprague Dawley rats by the DMAPA-Glyp derivatives, and then expressed as green fluorescence protein, compared with the control group.

Conclusion: The hyperbranched cationic glycogen derivatives, especially the DMAPA-Glyp derivatives, showed high gene-transfection efficiency, good blood compatibility, and low cytotoxicity when transfected in vitro and in vivo, which are novel potential nonviral gene vectors.

Keywords: glycogen, blood compatibility, cytotoxicity, gene delivery

\section{Introduction}

Gene therapy is considered a promising method to cure various diseases, such as cancer, diabetes, and genetic and autoimmune diseases. ${ }^{1}$ Although significant advances have been made in this research area, progress has been limited by the difficulties associated with delivery of negatively charged gene molecules into 
cells, because of their bulky volume and repulsion by the cell membranes. Furthermore, gene molecules are readily degraded by nuclease enzymes in the blood and cells. With this in mind, successful gene therapy would rely heavily on the development of effective gene-delivery vectors with high transfection efficiency and minimal cytotoxicity. ${ }^{2}$ Nonviral gene-delivery vectors, especially cationic polymers and liposomes, have attracted much attention in gene therapy. Recent work has established that the architecture of cationic polymers affects the stability, delivery, and transfection efficiency of their complexes with deoxyribonucleic acid (DNA). ${ }^{3-8}$ In contrast to linear cationic polymers, hyperbranched cationic polymers exhibit higher levels of gene expression, probably because of the following two factors: 1) they present compact and globular structures in combination with a significant number and variety of different amine groups, which are advantageous for the binding and condensation of DNA into compact particles, resulting in improved protection and endocytosis of DNA; ${ }^{4-7}$ and 2) they exhibit better proton-buffer capacity, which is beneficial for the escape of DNA from endosomes. ${ }^{4,8}$ Synthetic hyperbranched cationic polymers, however, such as branched polyethyleneimine (bPEI) and poly(amidoamine) (PAMAM) dendrimers, are still associated with cytotoxicity, biocompatibility, and biodegradability issues, which need to be overcome to allow for in vivo application..$^{9,10}$

Natural polysaccharides, due to their outstanding nontoxicity, good biocompatibility and biodegradability, and molecular diversity for chemical modification, have received increasing attention as gene-delivery vectors. ${ }^{11}$ Following amination, various cationized polysaccharide derivatives have been designed and synthesized as gene-delivery vectors, with high transfection efficiency. ${ }^{3,11-18}$ Glycogen is a storage form of glucose that occurs predominantly in the liver and skeletal muscles of mammalian and shellfish species. ${ }^{19}$ It is a natural hyperbranched polysaccharide with high weight-average molecular weight: about $10^{6}-10^{7} \mathrm{~g} / \mathrm{mol}{ }^{20,21}$ The individual linear chains of glycogen are composed of between ten and 14 glucose residues on average, with approximately one branching point for every ten glucose residues. ${ }^{19}$ Glycogen consists of a protein core and approximately 30,000 glucose units forming the branch-on-branch topological structure. ${ }^{22}$ Further studies have shown that glycogen exhibits a spherical and particular compact conformation with densely branched chains in aqueous solutions. ${ }^{20}$

Since glycogen comes from animals, good biocompatibility of glycogen derivatives is anticipated, which will be advantageous for gene therapy, such as for ischemic stroke. In this work, hyperbranched cationic glycogen derivatives conjugated with 3-(dimethylamino)-1-propylamine (DMAPA) and 1-(2aminoethyl) piperazine (AEPZ) residues were synthesized (Figure 1), and evaluated for their potential as nonviral genedelivery vectors. The formation process of cationic glycogen derivative/plasmid DNA (pDNA) complexes was characterized using agarose gel electrophoresis, zeta potential analysis, and atomic force microscopy (AFM). Blood compatibility and cytotoxicity were evaluated using the hemolysis assay and the 3-(4,5-dimethylthiazol-2-yl)-2,5-diphenyltetrazolium bromide (MTT) assay, respectively. pDNA transfection efficiency mediated by the cationic glycogen derivatives was evaluated by flow cytometry and fluorescence microscopy in the 293T (human embryonic kidney) and the CNE2 (human nasopharyngeal carcinoma) cell lines. In vivo delivery of pDNA in model animals (Sprague Dawley rats) was evaluated to identify safety and transfection efficiency.

\section{Materials and methods Materials}

Glycogen (from oysters), Triton X-100, ethidium bromide, DNase I, MTT, Hoechst 3334, and bPEI (25 kDa) were

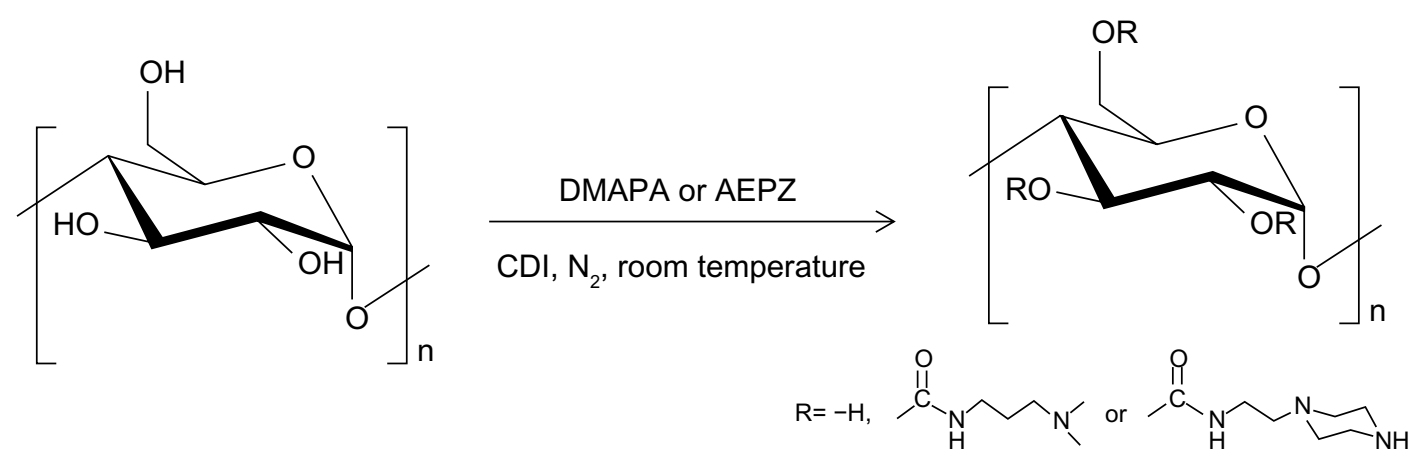

Figure I Synthesis of the hyperbranched cationic glycogen derivatives conjugated with 3-(dimethylamino)-I-propylamine (DMAPA) and I-(2-aminoethyl) piperazine (AEPZ) residues.

Abbreviation: CDI, N,N'-carbonyldiimidazole. 
purchased from Sigma-Aldrich (St Louis, MO, USA). $N, N^{\prime}-$ carbonyldiimidazole (CDI), DMAPA, AEPZ, and dimethyl sulfoxide (DMSO) were acquired from Aladdin Reagent (Shanghai, People's Republic of China). DMSO was dried for 1 week prior to use by soaking in molecular sieves and calcium hydride. Fetal bovine serum (FBS), Dulbecco's Modified Eagle's Medium (DMEM), penicillin-streptomycin, and trypsin were purchased from Life Technologies (Carlsbad, CA, USA). The reporter pDNA, plasmid enhanced green fluorescent protein (GFP)-N1 (4.7 kb), was supplied by Promega (Fitchburg, WI, USA). All of the other reagents were purchased as analytical grade and used without further purification.

\section{Synthesis and characterization of hyperbranched cationic glycogen derivatives}

DMAPA and AEPZ were introduced to the hydroxyl groups of glycogen according to the CDI activation method., ${ }^{3,12}$ Glycogen $(0.62 \mathrm{mmol}$ glucose units, $0.1000 \mathrm{~g})$ was dissolved in $10 \mathrm{~mL}$ of anhydrous DMSO, and subsequently activated by the addition of CDI $(5.58 \mathrm{mmol}, 0.9045 \mathrm{~g})$. The resulting mixture was then stirred for 1 hour in a nitrogen atmosphere at room temperature. DMAPA or AEPZ was added to the glycogen reaction solution according to the listed amounts (Table 1). The reaction was allowed to proceed for 24 hours in a nitrogen atmosphere at room temperature. The reaction solution was then dialyzed against the distilled water in a dialysis bag (molecular weight cutoff 14,000 ) for 3 days and lyophilized to yield the solid products, which were subsequently named DMAPA-Glyp and AEPZ-Glyp.

Fourier-transform infrared (FTIR) measurements were performed with a Nicolet/Nexus 670 FTIR analyzer (Thermo Fisher Scientific, Waltham, MA, USA) at a resolution of $4 \mathrm{~cm}^{-1}$ using the $\mathrm{KBr}$ method. Hydrogen-1 nuclear magnetic resonance ( ${ }^{1} \mathrm{H}$ NMR) analysis was carried out on a Varian Mercury Plus 300 NMR spectrometer (Varian, Palo Alto, $\mathrm{CA}, \mathrm{USA}$ ) at $35^{\circ} \mathrm{C}$ using deuterated water as the solvent. The signal at $\delta 4.67 \mathrm{ppm}$ for single-deuterated water was used as the internal standard. ${ }^{23}$ The degree of substitution (DS) of the oligoamine residues on the glycogen, defined as the number of oligoamine residues per glucose unit of glycogen, was determined by the integration of the resonance signal for the protons of the oligoamine residues and $\mathrm{H} 1$ of the glycogen.

DMAPA-Glyp: FTIR: $3,325 \mathrm{~cm}^{-1}\left(\mathrm{v}_{-\mathrm{OH}}\right), 2,819$ and $2,776 \mathrm{~cm}^{-1}\left(\mathrm{v}_{-{\mathrm{N}\left(\mathrm{CH}_{3}\right)_{2}}}\right), 1,709,1,546$ and $1,265 \mathrm{~cm}^{-1}$ $\left(v_{-\mathrm{C}=\mathrm{O}}, \delta_{-\mathrm{NH}-}\right.$, and $v_{-\mathrm{C}-\mathrm{N}}$ of carbamate groups), $1,459 \mathrm{~cm}^{-1}$ (deformation vibration of $-\mathrm{CH}_{2}-$ and $-\mathrm{CH}_{3}$ groups of DMAPA residues), 1,153 and $1,036 \mathrm{~cm}^{-1}\left(\mathrm{v}_{-\mathrm{C}-\mathrm{O}-\mathrm{C}-}\right.$ of
Table I Amounts of added oligoamines for synthesis of the cationic glycogen derivatives and their degrees of substitution

\begin{tabular}{llll}
\hline Sample $^{\text {a }}$ & $\begin{array}{l}\text { DMAPA } \\
(\mathbf{m m o l}, \mathbf{g})\end{array}$ & $\begin{array}{l}\text { AEPZ } \\
(\mathbf{m m o l}, \mathbf{g})\end{array}$ & DS $^{\mathbf{b}}$ \\
\hline DMAPA-Glyp-0.6 & $3.1,0.3168$ & - & 0.6 \\
DMAPA-Glyp-1.5 & $6.2,0.6335$ & - & 1.5 \\
DMAPA-Glyp-2.1 & $18.6,1.9005$ & - & 2.1 \\
DMAPA-Glyp-2.5 & $27.9,2.8508$ & - & 2.5 \\
DMAPA-Glyp-2.8 & $37.2,3.8011$ & - & 2.8 \\
AEPZ-Glyp-0.25 & - & $6.2,0.8024$ & 0.25 \\
AEPZ-Glyp-0.29 & - & $12.4,1.6049$ & 0.29 \\
AEPZ-Glyp-0.35 & - & $22.1,2.857$ & 0.35 \\
\hline
\end{tabular}

Notes: ${ }^{2}$ The numbers following DMAPA-Glyp and AEPZ-Glyp are the DS values; bdegree of substitution.

Abbreviations:DMAPA, 3-(dimethylamino)-I-propylamine;AEPZ, I-(2-aminoethyl) piperazine; Glyp, glycogen; DS, degree of substitution.

glycogen); ${ }^{1} \mathrm{H}$ NMR ( $\left.\mathrm{D}_{2} \mathrm{O}, \mathrm{ppm}\right): 5.30$ (glucose unit, $\mathrm{H} 1$ ), 4.50-3.50 (glucose unit, $\mathrm{H} 2-\mathrm{H} 6), 3.10\left(-\mathrm{CONH}-\mathrm{CH}_{2}-\right.$ ), $\left.2.34\left(-\mathrm{CH}_{2}-\mathrm{N}<\right), 2.18\left(-\mathrm{N}^{2} \mathrm{CH}_{3}\right]_{2}\right)$, and $1.63\left(-\mathrm{CH}_{2}-\right){ }^{18}$ DS $=0.6,1.5,2.1,2.5$, and 2.8 .

AEPZ-Glyp: FTIR: $3,390 \mathrm{~cm}^{-1}\left(v_{-\mathrm{OH},} v_{-\mathrm{NH}-}\right), 2,824 \mathrm{~cm}^{-1}$ $\left(\mathrm{v}_{-\mathrm{N}\left(\mathrm{CH}_{2}\right)_{2}}\right), 1,709,1,542$, and $1,252 \mathrm{~cm}^{-1}\left(\mathrm{v}_{-\mathrm{C}=\mathrm{O}}, \delta_{-\mathrm{NH}-}\right.$ and $v_{-\mathrm{C}-\mathrm{N}}$ of carbamate groups), $1,446 \mathrm{~cm}^{-1}$ (deformation vibration of $-\mathrm{CH}_{2}-$ groups of AEPZ residue), 1,144 and $1,027 \mathrm{~cm}^{-1}\left(\mathrm{v}_{-\mathrm{C}-\mathrm{O}-\mathrm{C}-}\right.$ of glycogen $) ;{ }^{1} \mathrm{H}$ NMR $\left(\mathrm{D}_{2} \mathrm{O}, \mathrm{ppm}\right)$ : 5.30 (glucose unit, H1), 4.50-3.50 (glucose unit, H2-H6), $2.80\left(-\mathrm{CH}_{2}-\mathrm{N}<\right.$ of ring $)$, and $2.47\left(-\mathrm{CH}_{2}-\mathrm{NH}-\right.$ of ring $){ }^{24}$ DS $=0.25,0.29$, and 0.35 .

\section{Hemolysis assay}

The hemolytic activities of the cationic glycogen derivatives and bPEI were investigated according to a method previously published in the literature. ${ }^{25}$ Sprague Dawley (SD) rats (weighing between 100 and $120 \mathrm{~g}$ ) were provided by the Center of Experimental Animals of Sun Yat-sen University and approved by the University Animal Study Committee. The erythrocytes were isolated from the blood of the SD rats by centrifugation at $111.8 \times g$ for 5 minutes and were washed in $0.9 \% \mathrm{NaCl}$ solution until the supernatant was clear. Then, the erythrocytes were diluted in a $0.9 \% \mathrm{NaCl}$ solution to $5 \times 10^{9}$ cells $/ \mathrm{mL}$. The obtained suspension $(100 \mu \mathrm{L})$ was incubated with $1 \mathrm{~mL}$ of the solution of glycogen derivatives and bPEI at different concentrations $(16-500 \mu \mathrm{g} / \mathrm{mL})$ at $37^{\circ} \mathrm{C}$ for 90 minutes. Following centrifugation at $111.8 \times g$ for 5 minutes, the supernatant was applied to a 96-well plate, and hemoglobin release was measured as the absorbance at $560 \mathrm{~nm}$ using a microplate reader (Wellscan MK3; Labsystems Dragon, Helsinki, Finland). A negative control solution ( $0 \%$ hemolysis) was prepared by adding a $0.9 \%$ $\mathrm{NaCl}$ solution to the erythrocyte suspension, and a positive 
control solution (100\% hemolysis) was prepared by adding $10 \%$ Triton X-100 to the erythrocyte suspension. The hemolysis rate was calculated according to the following equation:

$$
\text { Hemolysis rate }(\%)=\left(A-A_{0}\right) /\left(A_{100}-A_{0}\right) \times 100
$$

where $A, A_{0}$, and $A_{100}$ represent the absorbance values of the hemoglobin released solution incubated with the polymers and the values of the negative and positive control solutions, respectively. All of the samples were analyzed in triplicate. The morphology of the erythrocytes was observed on an Olympus (Tokyo, Japan) IX71 microscope.

\section{Buffer capacity}

The buffer capacity of the cationic glycogen derivatives and bPEI was determined by acid-base titration in accordance with procedures previously published in the literature. ${ }^{4,16}$ Each sample solution $(0.2 \mathrm{mg} / \mathrm{mL})$ was prepared in $30 \mathrm{~mL}$ of an aqueous $\mathrm{NaCl}$ solution $(0.15 \mathrm{~mol} /$ $\mathrm{mL})$. The sample solutions were initially titrated with a $0.1 \mathrm{~mol} / \mathrm{mL} \mathrm{NaOH}$ solution to a $\mathrm{pH}$ of 10.0 . Known volumes of a $0.1 \mathrm{~mol} / \mathrm{mL} \mathrm{HCl}$ solution were then added to the mixture to give solutions with different $\mathrm{pH}$ values, which were measured using a microprocessor $\mathrm{pH}$ meter (Shanghai Shengke Instrument and Equipment, Shanghai, People's Republic of China).

\section{Preparation of the cationic glycogen derivative/pDNA complexes}

The cationic glycogen derivatives $(10 \mathrm{mg})$ were dissolved in phosphate-buffered saline (PBS; $\mathrm{pH} 7.4$ ) solution at a concentration of $2 \mathrm{mg} / \mathrm{mL}$ and then filtered through a membrane filter (nominal pore size of $0.22 \mu \mathrm{m}$ ). A stock solution of pDNA (250 ng/ $\mu \mathrm{L})$ was prepared in PBS ( $\mathrm{pH} 7.4)$. A portion of pDNA solution ( $4 \mu \mathrm{L}$ ) was then added to the glycogen derivative solutions at different glycogen derivative/pDNA weight ratios. The resulting mixtures were then gently agitated for 5 seconds on a vortex agitator before being incubated at $37^{\circ} \mathrm{C}$ for 30 minutes prior to use.

\section{Agarose gel electrophoresis}

Electrophoresis was performed to assess pDNA-condensation ability of the glycogen derivatives and protection against DNase I degradation. pDNA was visualized and photographed using a Gel Doc XR gel image machine (Syngene, Cambridge, UK).

\section{pDNA condensation ability}

of the glycogen derivatives

Twenty microliters of the glycogen derivative/pDNA complexes with different glycogen derivative/pDNA weight ratios in the range of $0.1-20$ were loaded onto $0.8 \%$ agarose gels with ethidium bromide $(0.1 \mu \mathrm{g} / \mathrm{mL})$ and run with Tris-acetate running buffer at $90 \mathrm{~V}$ for 1 hour. DNA retardation was then observed by agarose gel electrophoresis.

\section{Protection against DNase I degradation}

DNase I (10 units, $2 \mu \mathrm{L}$ ) was added to $1 \mu \mathrm{g}$ of naked pDNA or glycogen derivative/pDNA complexes (with weight ratios of $2,5,10$, and 20 ) and incubated at $37^{\circ} \mathrm{C}$ with shaking at $100 \mathrm{rpm}$ for 30 minutes. The DNase I degradation process was then stopped by the addition of an ethylenediaminetetraacetic acid (EDTA) solution $(4 \mu \mathrm{L}, 250 \mathrm{mM})$, and pDNA was released following incubation with a heparin solution $(5 \mu \mathrm{L}, 0.1 \%, \mathrm{w} / \mathrm{v})$ at $37^{\circ} \mathrm{C}$ with shaking at $100 \mathrm{rpm}$ over a period of 3.5 hours. The samples were loaded onto the gel and electrophoresed to examine the integrity of pDNA.

\section{Measurements of zeta potentials and particle sizes}

Solutions of glycogen derivative/DNA complexes with different weight ratios $(2 \mathrm{~mL})$ were prepared in double-distilled water to a final concentration of $1.0 \mu \mathrm{g} / \mathrm{mL}$ for pDNA. The sample mixtures were gently agitated on a vortex agitator for 5 seconds before being incubated at $37^{\circ} \mathrm{C}$ for 30 minutes, and then filtered through a membrane filter (nominal pore size of $0.45 \mu \mathrm{m}$ ). The particle sizes and zeta potentials of the glycogen derivative/pDNA complexes were measured using ZetaPALS (Brookhaven Instruments, Holtsville, NY, USA) at $25^{\circ} \mathrm{C}$ with a $90^{\circ}$ scattering angle. All of the measurements were performed in triplicate.

\section{AFM observations}

One milliliter of solutions of pDNA and the DMAPA-Glyp2.8/pDNA complex (with weight ratios of $0.3,0.5,2$, and 20) were prepared in the AFM buffer to a final concentration of $2.5 \mu \mathrm{g} / \mathrm{mL}$ for $\mathrm{pDNA}$. The AFM buffer included Tris-EDTA buffer (10 mmol/L Tris-HCl and $1 \mathrm{mmol} / \mathrm{L}$ EDTA, $\mathrm{pH}$ 8.0) and $5 \mathrm{mmol} / \mathrm{L} \mathrm{MgCl}_{2}$. To successfully image pDNA molecules and investigate the interactions between pDNA and the DMAPA-Glyp-2.8 derivative, pDNA molecules were extended following the methods used in a previous work. ${ }^{26}$ The sample solution $(20 \mu \mathrm{L})$ was dropped on a freshly cleaved mica surface and left to stand for 5 minutes. Then, the mica 
surface was tilted at $45^{\circ}$ from level, allowing the solution to slide slowly to the bottom edge. The treated mica surface was washed with distilled water eight times by the same method. The distilled water was then evaporated at room temperature under vacuum for 2 weeks. AFM images of $256 \times 256$ pixels were performed on a MultiMode 8 atomic force microscope (Bruker Optics, Billerica, MA, USA) in tapping mode, and the images were analyzed using NanoScope software (Bruker). Silicon tips (TESP; Bruker) were used with a force constant of $40 \mathrm{~N} / \mathrm{m}$.

\section{Cytotoxicity assay}

Cells from the 293T and CNE2 cell lines were seeded in 96-well plates at a density of $1 \times 10^{4}$ cells/well in $200 \mu \mathrm{L}$ DMEM containing $10 \%$ FBS and subsequently cultured at $37^{\circ} \mathrm{C}$ for 24 hours. The medium was then replaced with a fresh serum-free medium, and the solutions of the glycogen derivatives and bPEI at different concentrations were added to the culture medium of each well to assess their cytotoxicity. In addition, $200 \mu \mathrm{L}$ of the glycogen derivative/ pDNA complexes with different weight ratios were added for the cytotoxicity assay. The content of pDNA was set at $0.2 \mu \mathrm{g}$ for each complex. The bPEI and the bPEI/pDNA complex were used as the positive controls. After the cells were incubated for an additional 24 hours, $20 \mu \mathrm{L}$ of MTT ( $5 \mathrm{mg} / \mathrm{mL}$ ) in PBS (pH 7.4) was added to each well to give a final concentration of $0.5 \mathrm{mg} / \mathrm{mL}$. The cells were further incubated for 4 hours, and DMSO $(150 \mu \mathrm{L})$ was then added to dissolve the formazan crystals formed in the live cells. Using a spectrometer, the absorbance values of the samples were measured at $560 \mathrm{~nm}$. Cell viability was then calculated according to the following equation:

$$
\text { Cell viability }(\%)=\left(A_{560 \text {-sample }} / A_{560-\text { control }}\right) \times 100
$$

where $A_{560-\text { sample }}$ and $A_{560-\text { control }}$ were obtained in the presence and absence of the glycogen derivatives, respectively. All of the experiments were conducted five times.

\section{In vitro transfection by flow cytometry and fluorescence microscopy}

Cells from the 293T and CNE2 cell lines were plated in 24-well plates at a density of $1 \times 10^{5}$ cells/well in $200 \mu \mathrm{L}$ of DMEM containing $10 \% \mathrm{FBS}$ and subsequently cultured at $37^{\circ} \mathrm{C}$ for 24 hours. The media were then replaced with serum-free media containing the glycogen derivative/ pDNA complexes and the bPEI/pDNA complex at different weight ratios, as well as $2 \mu \mathrm{g}$ of pDNA. The bPEI/pDNA complex was used as the positive control, whereas the naked pDNA was used as the negative control. Following a 4-hour period of incubation, the serum-free media were changed with fresh media containing 10\% serum. Following a further 36-hour period of incubation, the cells were directly observed on a DMI4000B fluorescence microscope (Leica Microsystems, Wetzlar, Germany). The transfected cells were then washed once with PBS $(\mathrm{pH}$ 7.4) and detached with $0.25 \%$ trypsin. Using an FACSAria flow cytometer (BD Biosciences, San Jose, CA, USA), the gene-transfection efficiency was evaluated by scoring the percentage of cells expressing GFP. All of the experiments were conducted in triplicate.

\section{Observation of intracellularly expressed GFP}

The glycogen derivative/pDNA complexes ( $\mathrm{w} / \mathrm{w}=20)$ were incubated with cells from the 293T cell line for 4 hours under the conditions mentioned earlier. Following a further incubation period of 36 hours, the cells were washed with PBS (pH 7.4) before being fixed in 4\% paraformaldehyde for 30 minutes. For the labeling of the nucleus, the fixed cells were washed three times with PBS ( $\mathrm{pH}$ 7.4) before being incubated with Hoechst 33342 for 10 minutes. The cells were then washed three times with PBS ( $\mathrm{pH} 7.4)$, and the intracellular expression of GFP in the cells was observed with an LSM710 confocal microscope (Carl Zeiss Meditec, Jena, Germany) equipped with argon (488 nm) and $\mathrm{He}-\mathrm{Ne}$ (543 nm) lasers.

\section{In vivo evaluation of GFP expression}

SD rats (weighing 200-250 g) were obtained from the Center of Experimental Animals of Sun Yat-sen University. All procedures were approved by the Animal Care and Use Committee of Sun Yat-sen University, and in accordance with National Institutes of Health's Guide for the Care and Use of Laboratory Animals. The SD rats were anesthetized by intramuscular injection of a $10 \%$ chloral hydrate solution. Then, an animal model of middle cerebral artery occlusion (MCAO) was established. A solution of the DMAPA-Glyp2.5/pDNA complex $(0.6 \mathrm{~mL}, \mathrm{w} / \mathrm{w}=20$, a final concentration of $50 \mu \mathrm{g} / \mathrm{mL}$ for pDNA) was injected into the carotid by the improved catheter method in the experimental groups $(n=3)$. The SD rats with MCAO were injected with saline as the control group $(n=3)$. On the fifth day, the SD rats were killed with a lethal dose of chloral hydrate, and were transcardially 
perfused with a saline solution, followed by adding $400 \mathrm{~mL}$ paraformaldehyde $(4 \%)$ in $0.1 \mathrm{~mol} / \mathrm{L} \mathrm{PBS}$. The brain tissues were then taken out, fixed overnight in the paraformaldehyde solution, and cryoprotected in 30\% sucrose. After they were embedded in an optimum cutting temperature compound, the brain tissues were cut into cryosections of $4 \mu \mathrm{m}$ thickness on a cryostat (Microtome Cryostat HM 550; Microm International, Walldorf, Germany). The cryosections were washed three times with PBS before being stained with Hoechst 33342 for 10 minutes, and finally the expression of GFP in blood vessels of brain tissue was observed with the Zeiss LSM710 confocal microscope.

\section{Statistical analysis}

Statistical analyses were performed by one-factor analysis of variance (SPSS version 13.0; IBM, Armonk, NY, USA). The results were expressed as means \pm standard deviation, with a value of $P<0.05$ being considered statistically significant.

\section{Results and discussion}

\section{Synthesis of hyperbranched}

\section{cationic glycogen derivatives}

To form complexes with negatively charged pDNA, the cationic glycogen derivatives were synthesized under mild conditions by conjugation of DMAPA or AEPZ with the hydroxyl groups of glycogen using the conventional CDI activation method at room temperature. ${ }^{3,12}$ From the FTIR spectra shown in Figure 2A, it was clear that a strong absorption peak of glycogen derivatives at $1,709 \mathrm{~cm}^{-1}$ was different from that of glycogen, which could be assigned to the $-\mathrm{C}=\mathrm{O}$ vibration of the carbamate groups. ${ }^{18}$ Furthermore, the absorption peaks at 1,540-1,550 and 1,250-1,270 $\mathrm{cm}^{-1}$ were attributed to the $-\mathrm{NH}-$ and $\mathrm{C}-\mathrm{N}$ vibrations of the carbamate groups, respectively. ${ }^{18}$ These results indicated that the DMAPA or AEPZ residues were conjugated to glycogen with carbamate linkages. In the ${ }^{1} \mathrm{H}$ NMR spectra of DMAPA-Glyp and AEPZ-Glyp derivatives (Figure 2B), the proton resonance peaks at 1.0-3.2 ppm provided further confirmation that the oligoamine residues were conjugated with glycogen. ${ }^{18,24}$ The DS values of the AEPZ-Glyp derivatives, however, were lower than those of the DMAPA-Glyp derivatives (Table 1), because of the steric hindrance between the AEPZ residues and the glucose units of glycogen.

\section{Blood compatibility analysis}

The nonspecific interactions of the cationic polymers with components in the blood could severely diminish the halflife and targetability of complexes, as well as the reproducibility of such therapies. ${ }^{27}$ The poor stability of these delivery vehicles in the blood has therefore been considered
A

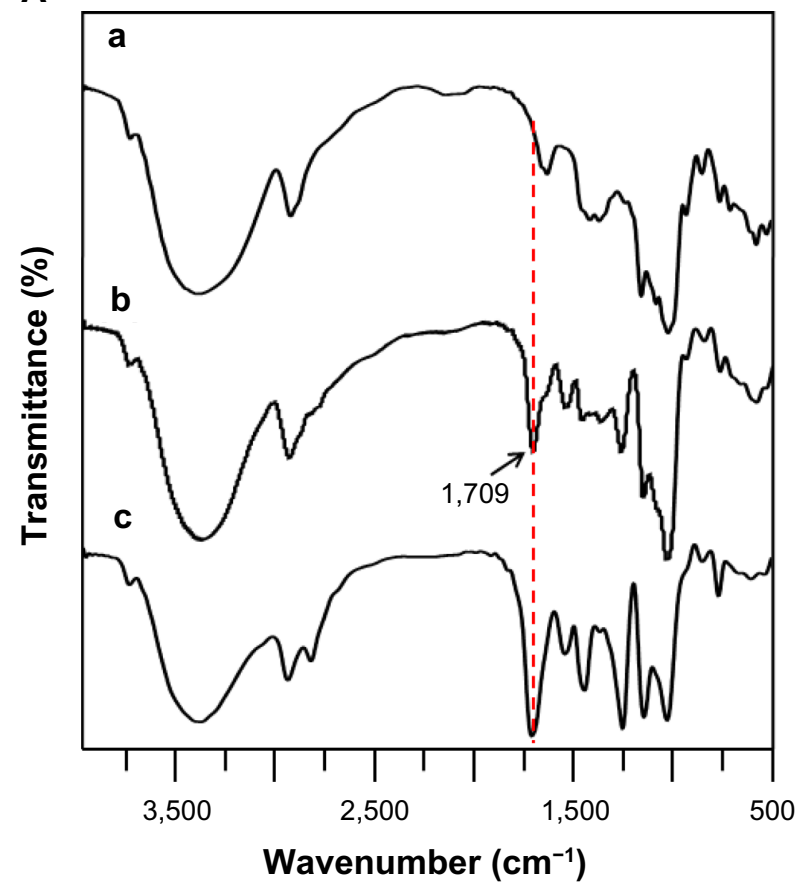

B

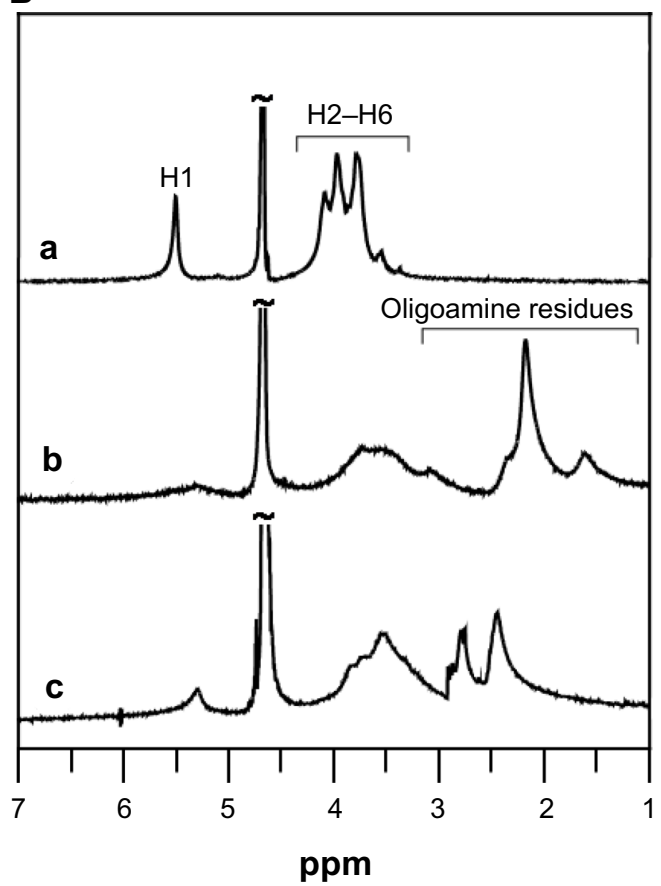

Figure 2 (A) Fourier-transform infrared spectra and (B) hydrogen-I nuclear magnetic resonance spectra of glycogen and its derivatives: glycogen (a), DMAPA-Glyp-0.6 (b), and AEPZ-Glyp-0.35 (c).

Abbreviations: DMAPA, 3-(dimethylamino)-I-propylamine; AEPZ, I-(2-aminoethyl) piperazine; Glyp, glycogen. 
to be one of the serious limitations in the therapeutic application of cationic polymers. ${ }^{27,28}$ As shown in Figure 3A $(\mathrm{a}-\mathrm{f})$, the hemolytic phenomenon was only observed at high concentrations of the glycogen derivatives ( $\geq 250 \mu \mathrm{g} / \mathrm{mL}$ ), after they were incubated with the erythrocytes. The hemolytic phenomenon became more pronounced, however, in the presence of bPEI (Figure 3A [g]), mainly because of the erythrocyte membrane disruption. The blood compatibility of the cationic glycogen derivatives was further assessed by spectrophotometric measurement of hemoglobin release from the erythrocytes following the polymer treatment. The result indicated that the hemolysis rates for all of the glycogen derivatives were less than $9 \%$, suggesting low hemolytic activity, because of the good biocompatibility of glycogen (Figure 3B). In addition, the hemolysis rates of both glycogen derivatives were similar at the lower concentration $(\leq 63 \mu \mathrm{g} / \mathrm{mL})$. At the higher concentration $(\geq 125 \mu \mathrm{g} / \mathrm{mL}$ ), the hemolysis rates of the DMAPA-Glyp derivative groups were gradually higher than those of the AEPZ-Glyp derivative groups, and the hemolysis rates generally increased with increasing DS values. This implied that blood compatibility was related to the type and content of the oligoamine residues conjugated to each of the different glycogen derivatives. The AEPZ-Glyp derivatives, which were composed of a low content of ring oligoamine residues, exhibited better blood compatibility than the DMAPA-Glyp derivatives, which were composed of a high content of linear high-density tertiary amines. In contrast, bPEI caused serious hemolysis in a_concentration-dependent manner.
The majority of erythrocytes appeared as normal cells in the shape of biconcave discs after they were incubated with the glycogen derivatives, which showed no obvious change compared with those in a $0.9 \% \mathrm{NaCl}$ solution (Figure S1). However, the erythrocytes incubated with bPEI deformed and aggregated because of stronger interactions between the erythrocytes and bPEI. These results indicated that the blood compatibility of the glycogen derivatives was better than that of bPEI.

\section{Buffer capacity}

PEI and PAMAM are known as "proton-sponge" polymers, which have high buffer capacity over a broad $\mathrm{pH}$ value. Therefore, they can lead an increase of swelling of endocytic vesicles to help DNA complexes escape into the cytoplasm, resulting in relatively high gene-transfer activity. ${ }^{29,30}$ This unique property is due to a large number of secondary and tertiary amines of the polymers. ${ }^{29,30}$ The buffer capacity of cationic glycogen derivatives in aqueous $\mathrm{NaCl}$ solution was assessed by acid-base titration. As shown in Figure 4, the buffer capability of glycogen was improved after being conjugated with oligoamine residues. The DMAPA-Glyp derivatives (DS >2.0) exhibited significantly higher buffer capability than the AEPZ-Glyp and DMAPA-Glyp- 1.5 derivatives, owing to their different type and content of oligoamine residues. However, the glycogen derivatives exhibited lower buffer capability than bPEI, due to the presence of relatively fewer amine groups on the derivatives.
A

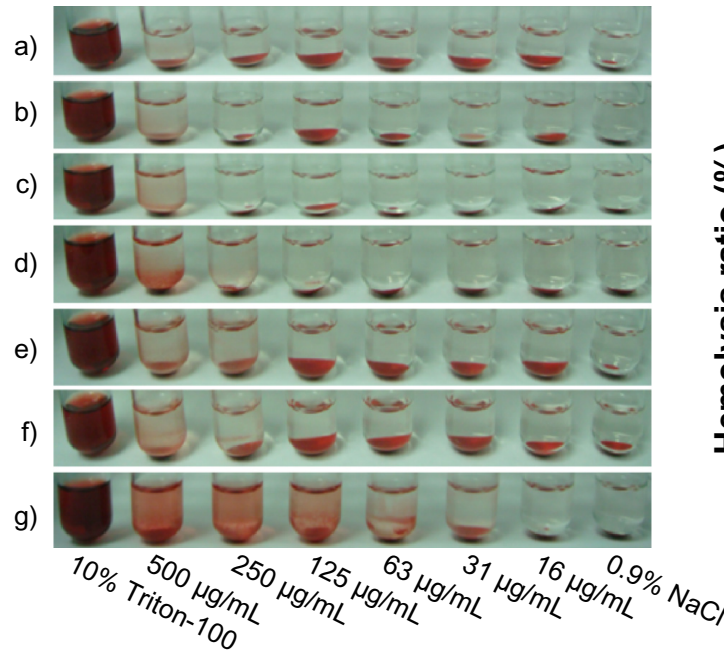

B

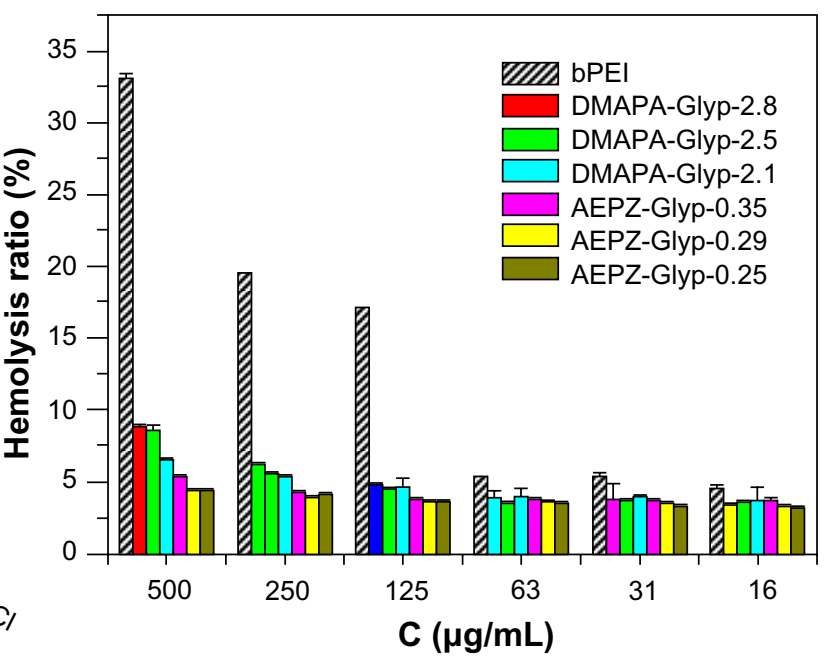

Figure 3 (A) Visual observation of hemolysis caused by AEPZ-Glyp-0.25 (a), AEPZ-Glyp-0.29 (b), AEPZ-Glyp-0.35 (c), DMAPA-Glyp-2.I (d), DMAPA-Glyp-2.5 (e), DMAPAGlyp-2.8 (f), and bPEI (g). (B) Change of hemolysis rate with the concentration of glycogen derivatives and bPEI $(n=3)$.

Abbreviations: DMAPA, 3-(dimethylamino)-I-propylamine; AEPZ, I-(2-aminoethyl) piperazine; Glyp, glycogen; bPEl, branched polyethyleneimine; C, concentration. 


\section{Complex formation of cationic glycogen derivatives with pDNA}

The formation of the cationic glycogen derivative/pDNA complexes was examined by agarose gel electrophoresis using pDNA as a control. As shown in Figure 5A, the migration of pDNA was retarded when the DMAPA-Glyp derivative/ pDNA and the AEPZ-Glyp derivative/pDNA weight ratios exceeded 1 and 5, respectively. The result suggested that the glycogen derivatives possessed good pDNA-binding ability because of their cationic oligoamine residues. The higher binding ability of the DMAPA-Glyp derivatives with pDNA arises from their higher DS values, ie, more oligoamine residues are widely distributed in the DMAPA-Glyp derivatives compared with the AEPZ-Glyp derivatives.

We recently reported hyperbranched cationic amylopectin derivatives conjugated with the same content of DMAPA residues as the DMAPA-Glyp-2.8 derivative for gene delivery, named the DMAPA-Amp-2. 8 derivative. ${ }^{18}$ It should be noted that the weight ratio of the DMAPA-Glyp2.8 derivative/pDNA complex (at 1 ) was lower than that of the DMAPA-Amp-2.8 derivative/pDNA complex (at 5), ${ }^{18}$ when the migration of pDNA was completely retarded. In contrast to amylopectin, the fraction of branching units for glycogen is higher at $8 \%$, whereas the value is $5 \%-6 \%$ for amylopectin. ${ }^{21}$ Therefore, the result may indicate that pDNA-binding and -condensation abilities are enhanced with the increase in the fraction of branching units of the hyperbranched polysaccharide derivatives, in agreement with the literature..$^{4-7}$ This is closely related to their genedelivery efficacy, which needs to be investigated in the future.

\section{Protection of pDNA by the cationic glycogen derivatives}

The protection effect of the complexes against DNA degradation by DNase I is shown in Figure 5B. While naked pDNA was completely digested (lane 2), the migration of pDNA was observed after the glycogen derivatives/ pDNA complexes were digested by DNase I and treated with heparin solution, at weight ratios above 2 and 5 for

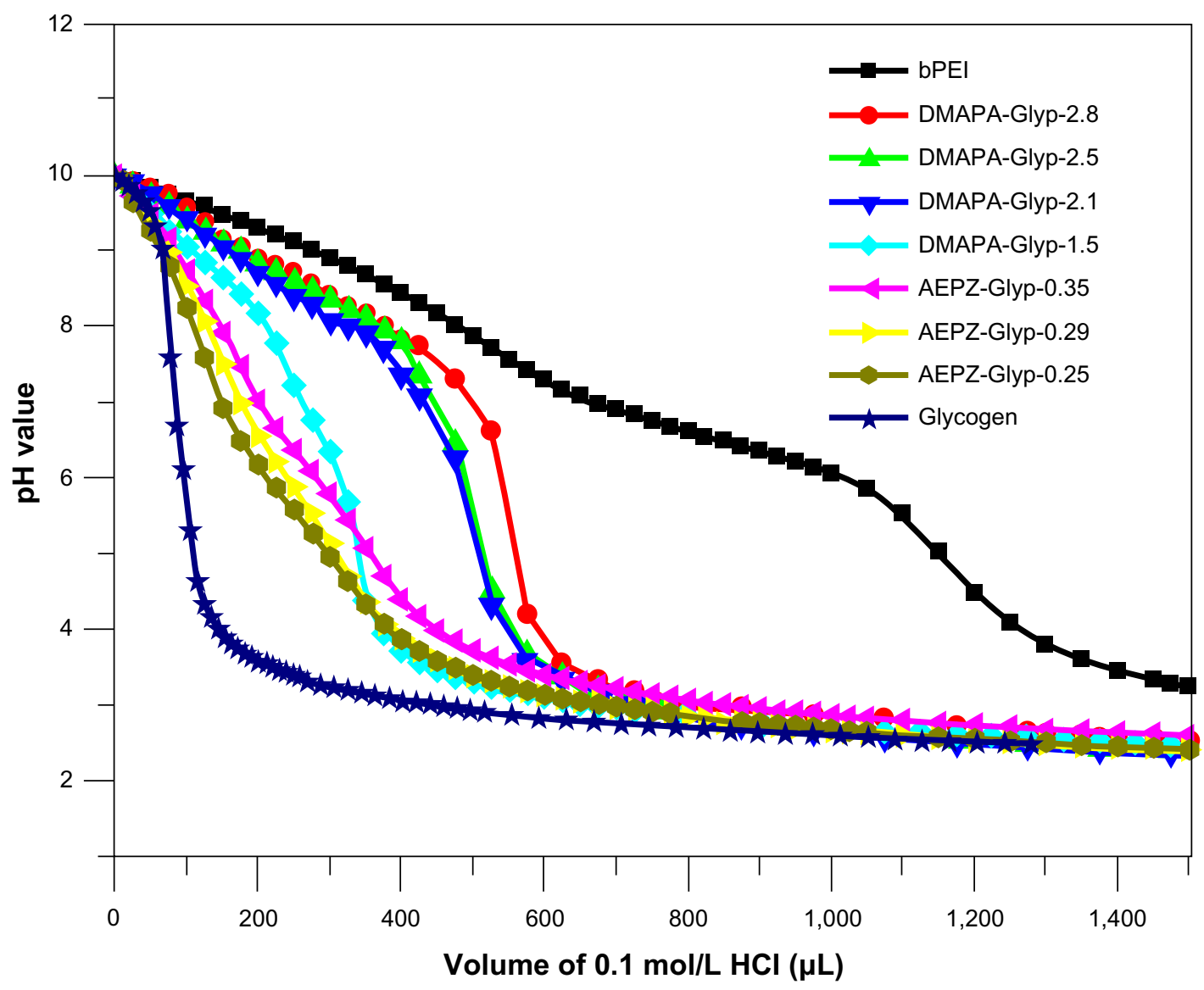

Figure 4 Acid-base titration profiles of cationic glycogen derivatives and bPEl in aqueous $0.15 \mathrm{~mol} / \mathrm{L} \mathrm{NaCl}$ solutions (sample solution, $0.2 \mathrm{mg} / \mathrm{mL}$ ). Abbreviations: DMAPA, 3-(dimethylamino)-I-propylamine; AEPZ, I-(2-aminoethyl) piperazine; Glyp, glycogen; bPEI, branched polyethyleneimine. 


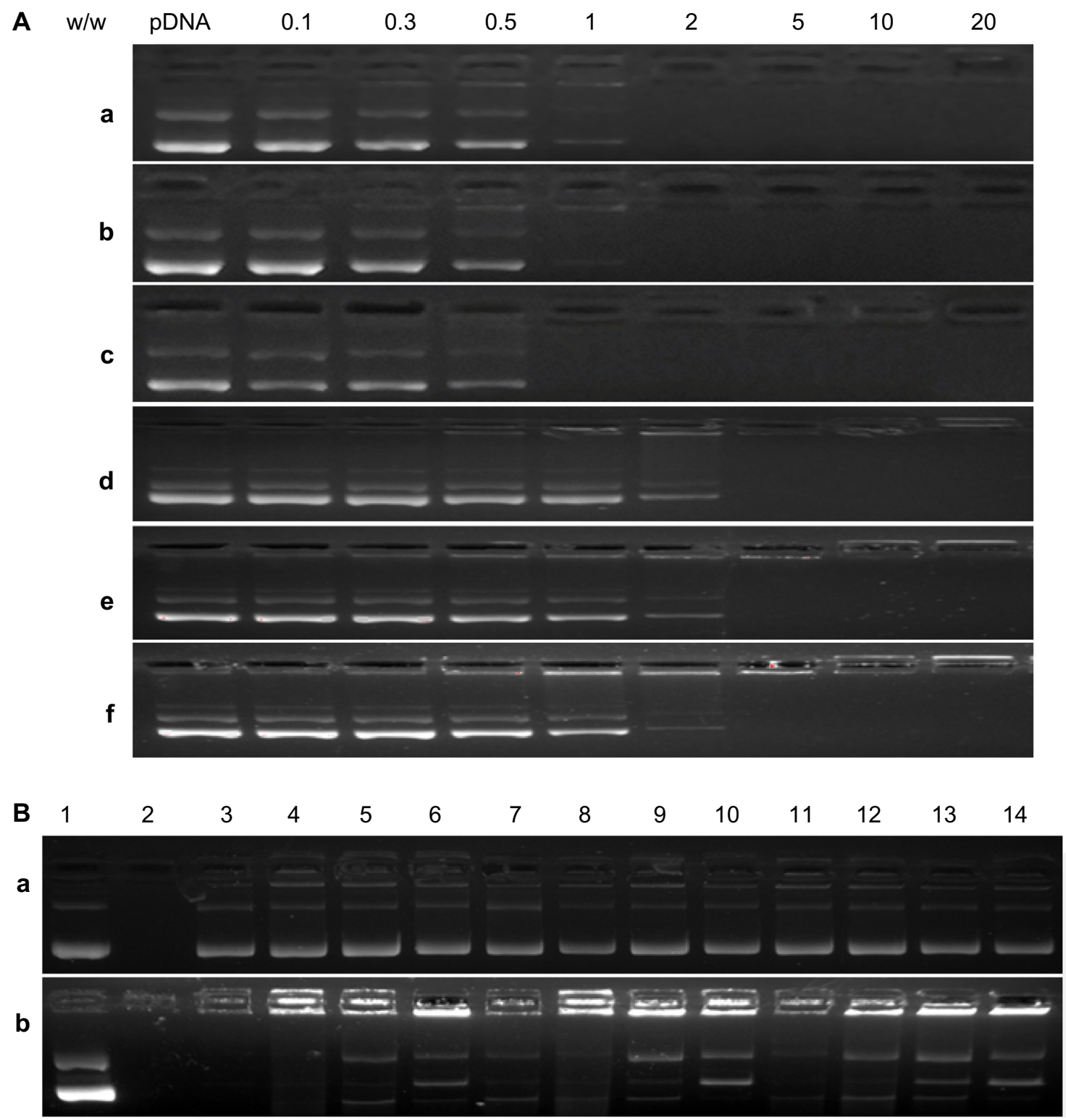

Figure 5 (A) Agarose gel electrophoresis retardation assay of glycogen derivative/pDNA complexes at different weight ratios: DMAPA-Glyp-2.I (a), DMAPA-Glyp-2.5 (b), DMAPA-Glyp-2.8 (c), AEPZ-Glyp-0.25 (d), AEPZ-Glyp-0.29 (e), and AEPZ-Glyp-0.35 (f). (B) Protection and release assay of pDNA. Lane I, naked pDNA; lane 2, naked pDNA digested by DNase I; lanes 3- 14 , glycogen derivative/pDNA complexes ( $w / w=2,5,10$, and 20 ) digested by DNase l and treated with heparin solution (lanes a3-a6, DMAPAGlyp-2.I; lanes a7-a I0, DMAPA-Glyp-2.5; lanes a I I-a 14, DMAPA-Glyp-2.8; lanes b3-b6, AEPZ-Glyp-0.25; lanes b7-b I0, AEPZ-Glyp-0.29; lanes b| I-b|4, AEPZ-Glyp-0.35). Abbreviations: DMAPA, 3-(dimethylamino)-I-propylamine; AEPZ, I-(2-aminoethyl) piperazine; Glyp, glycogen; pDNA, plasmid deoxyribonucleic acid.

the DMAPA-Glyp/pDNA and the AEPZ-Glyp/pDNA complexes, respectively (lanes 3-14). This demonstrated that the glycogen derivatives exhibited distinct protective effects against DNase I.

\section{Analysis of zeta potentials and particle sizes}

It has been reported that cationic polymers/DNA complexes with positive surface charge and sizes between 50 to several hundred nanometers would be suitable for the endocytosis of complexes and efficient gene delivery. ${ }^{16,29,31}$ As shown in
Figure 6A, the zeta potential of the glycogen derivative/pDNA complexes increased with increasing weight ratios. After the complexes formed, their zeta potentials became positive, which is amenable to the effective condensation of DNA. For example, the zeta potential of the DMAPA-Glyp/pDNA complexes increased from $2 \mathrm{mV}$ to $23 \mathrm{mV}$ when the weight ratio increased from 2 to 20 . In addition, the result revealed that the content and type content of the oligoamine residues of the cationic glycogen derivatives had a small effect on the zeta potential. The pDNA condensation of the glycogen derivatives was attributed to their cationic properties, of 
which zeta potentials were all in the range of $15-35 \mathrm{mV}$, and increased with increased DS values (Figure S2). As expected, the average particle size of the glycogen derivative/ pDNA complexes decreased with increased weight ratios, ie, the complexes became progressively smaller during the pDNA-condensation process (Figure 6B). For example, the complexes condensed from about $600 \mathrm{~nm}(\mathrm{w} / \mathrm{w}=0.1)$ to $150-250 \mathrm{~nm}(\mathrm{w} / \mathrm{w}=20)$.

\section{Observation of complex-formation process by AFM}

The process of DMAPA-Glyp-2.8 derivative/pDNA complex formation was observed by AFM (Figure 7). The extended pDNA molecules can be clearly seen in the AFM images of pDNA following the stretch orientation (Figure 7A), which matches the pDNA images reported in the literature. ${ }^{26}$ It was observed that the pDNA molecules gradually attached to the DMAPA-Glyp-2.8 derivative with increased weight ratio from 0.3 to 0.5 (Figure $7 \mathrm{~B}$ and $\mathrm{C}$ ). When the weight ratio exceeds 2, the DMAPA-Glyp-2.8 derivative can condense pDNA into global particles with size ranging from
90 to $140 \mathrm{~nm}$ (Figure 7D and E). These results further confirm that the DMAPA-Glyp-2.8 derivative and pDNA can form a condensed complex.

\section{Cytotoxicity analysis}

It is considered that cytotoxicity of cationic polymers is another important factor of biocompatibility together with blood compatibility. ${ }^{25}$ In vitro cytotoxicity of the glycogen derivatives and bPEI was thus assessed at concentrations ranging from 16 to $500 \mu \mathrm{g} / \mathrm{mL}$ by MTT assay in the $293 \mathrm{~T}$ and CNE2 cells. As shown in Figure 8A and B, the cell viability of the AEPZ-Glyp derivatives was generally higher than that of DMAPA-Glyp, implying that cytotoxicity was related to the type and content of the oligoamine residues conjugated to the glycogen derivatives. However, the result also revealed that the cell viability of the glycogen derivatives was higher than that of bPEI, indicating the glycogen derivatives exhibited lower cytotoxicity. This difference could be attributed to the biocompatibility of glycogen.

The cytotoxicity of the glycogen derivative/pDNA complexes with various weight ratios was further evaluated in the
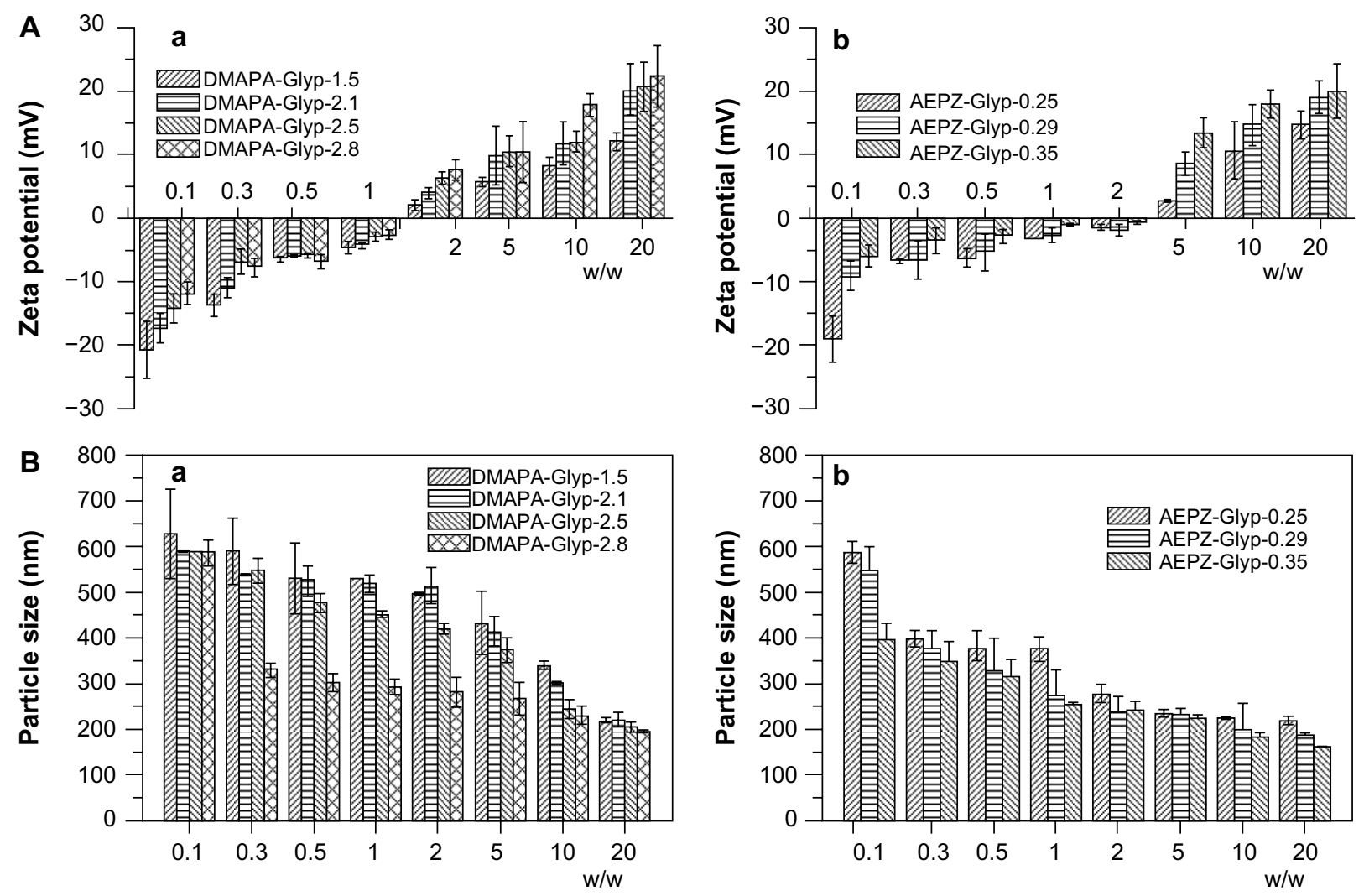

Figure 6 (A) Zeta potential and (B) average particle size of glycogen derivative/pDNA complexes at various weight ratios: the DMAPA-Glyp/pDNA complexes (a), and the AEPZ-Glyp/pDNA complexes $(n=3)(\mathbf{b})$.

Abbreviations: DMAPA, 3-(dimethylamino)-I-propylamine; AEPZ, I-(2-aminoethyl) piperazine; Glyp, glycogen; pDNA, plasmid deoxyribonucleic acid. 

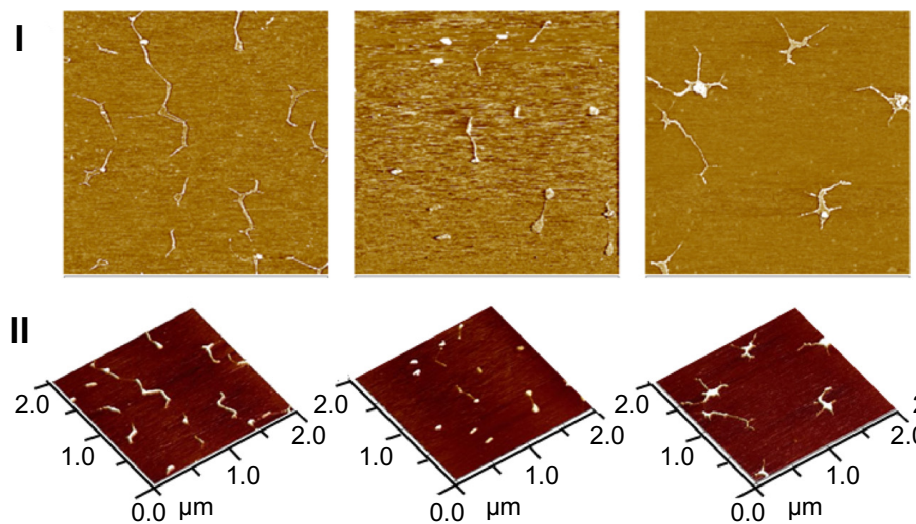

a

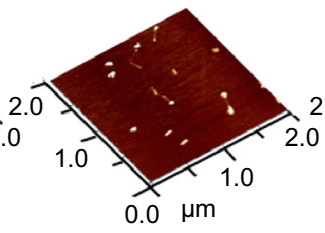

b

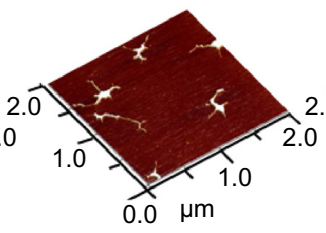

C
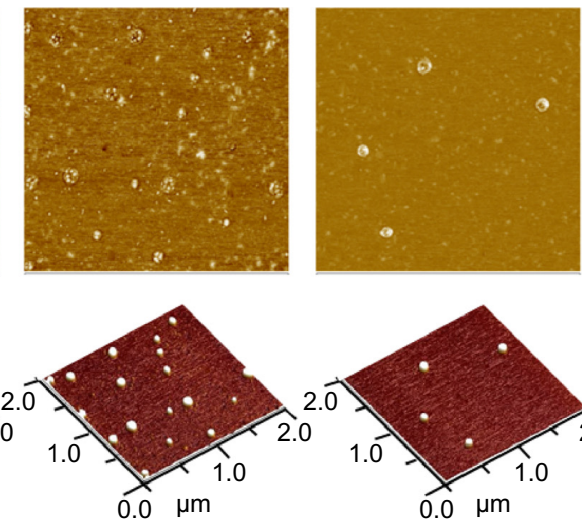

d

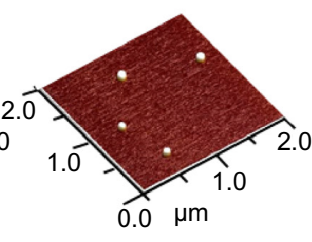

e

Figure 7 Atomic force microscopy images of (a) pDNA and the pDNA/DMAPA-Glyp-2.8 complex with different weight ratios: (b) $w / w=0.3,(\mathbf{c})$ w/w $=0.5$, (d) $w / w=2$, and (e) $w / w=20$. I: Phase-mode images. Each image represents a $2 \times 2 \mu \mathrm{m}$ scan. II: Height-mode images.

Abbreviations: DMAPA, 3-(dimethylamino)-I-propylamine; Glyp, glycogen; pDNA, plasmid deoxyribonucleic acid.

293T and CNE2 cells by MTT assay. As a result of the lower cytotoxicity of the glycogen derivatives, the cell viability of the glycogen derivative/pDNA complexes was higher than that of the $\mathrm{bPEI} / \mathrm{pDNA}$ complexes at weight ratios ranging from 2 to 80 (Figure $8 \mathrm{C}$ and $\mathrm{D}$ ).

\section{In vitro transfection of pDNA}

The gene-transfer capacity of the cationic glycogen derivatives was evaluated in the $293 \mathrm{~T}$ and CNE2 cell lines. Transfection efficiency was quantitatively determined using flow cytometry to assess the actual percentage of GFP-expressing cells. According to previous work, ${ }^{29}$ the $\mathrm{bPEI} / \mathrm{pDNA}$ complex $(\mathrm{N} / \mathrm{P}=10, \mathrm{~N} / \mathrm{P}$ ratio refers to the ratio of moles of the amine groups of bPEI to moles of phosphates of pDNA) was used as a control. As shown in Figure 9A, the transfection efficiency of the DMAPA-Glyp/pDNA complexes was significantly higher than that of the AEPZ-Glyp/pDNA complexes in both cells. Noticeably, the transfection efficiency of the DMAPAGlyp-2.8/pDNA complex (w/w =20) was almost equal to that of the bPEI/pDNA complex. The high transfection efficiency of the DMAPA-Glyp derivatives is likely related to their good buffer capability and high pDNA-condensation ability. In addition, it was found that the gene-transfection efficiency of the cationic glycogen derivative/pDNA complexes was dependent on the weight-ratio values, the cell types, and the oligoamine residues of the glycogen derivatives. At the weight ratio of 5 , the complexes exhibited low gene-transfer capacity in the two cell lines. However, the transfection efficiency of the complexes increased with increasing weight ratios. The genetransfer capacity of the cationic glycogen derivatives in the 293 T cells was higher than that observed in the CNE2 cells, attributed to distinct endocytosis ability of the 293T cells The transfection of naked pDNA was less than $0.3 \%$ in the two cell lines, further confirming that the cationic glycogen derivatives have the capability to protect pDNA and improve expression levels of GFP.

GFP-expressing cells were observed using an inverted fluorescence microscope to further visualize the transfection efficiency of the glycogen derivative/pDNA complexes ( $\mathrm{w} / \mathrm{w}=20)$. In comparison with the AEPZ-Glyp-0.35/pDNA group (Figure 9B [a1]), a strong green fluorescent signal was observed in $293 \mathrm{~T}$ cells transfected with the complexes of DMAPA-Glyp-2.8/pDNA and bPEI/pDNA (9B [b1, c1]), further highlighting the high transfection efficiency found by flow cytometry. Additionally, the transfection efficiency of the glycogen derivatives was found to be higher in the 293T cells than in the CNE2 cells.

The expressed GFP was observed throughout the cytoplasm and nuclei of the $293 \mathrm{~T}$ cells in the laser-scanning confocal images (Figure S3). The GFP fluorescence intensity in the cells incubated with the DMAPA-Glyp-2.8/pDNA complex was much stronger than that in the cells incubated with the AEPA-Glyp-0.35/pDNA complex, further confirming the higher gene-transfer efficiency of the DMAPA-Glyp-2.8/ pDNA complex. In comparison, the nuclei became bright blue, shrank, and deformed following incubation of the cells with bPEI/pDNA, suggesting that apoptosis occurred as a consequence of the cytotoxicity of bPEI.

\section{In vivo evaluation of GFP expression}

All SD rats were still alive on the fifth day following injection of the DMAPA-Glyp-2.5/pDNA complex (Figure 10A), 

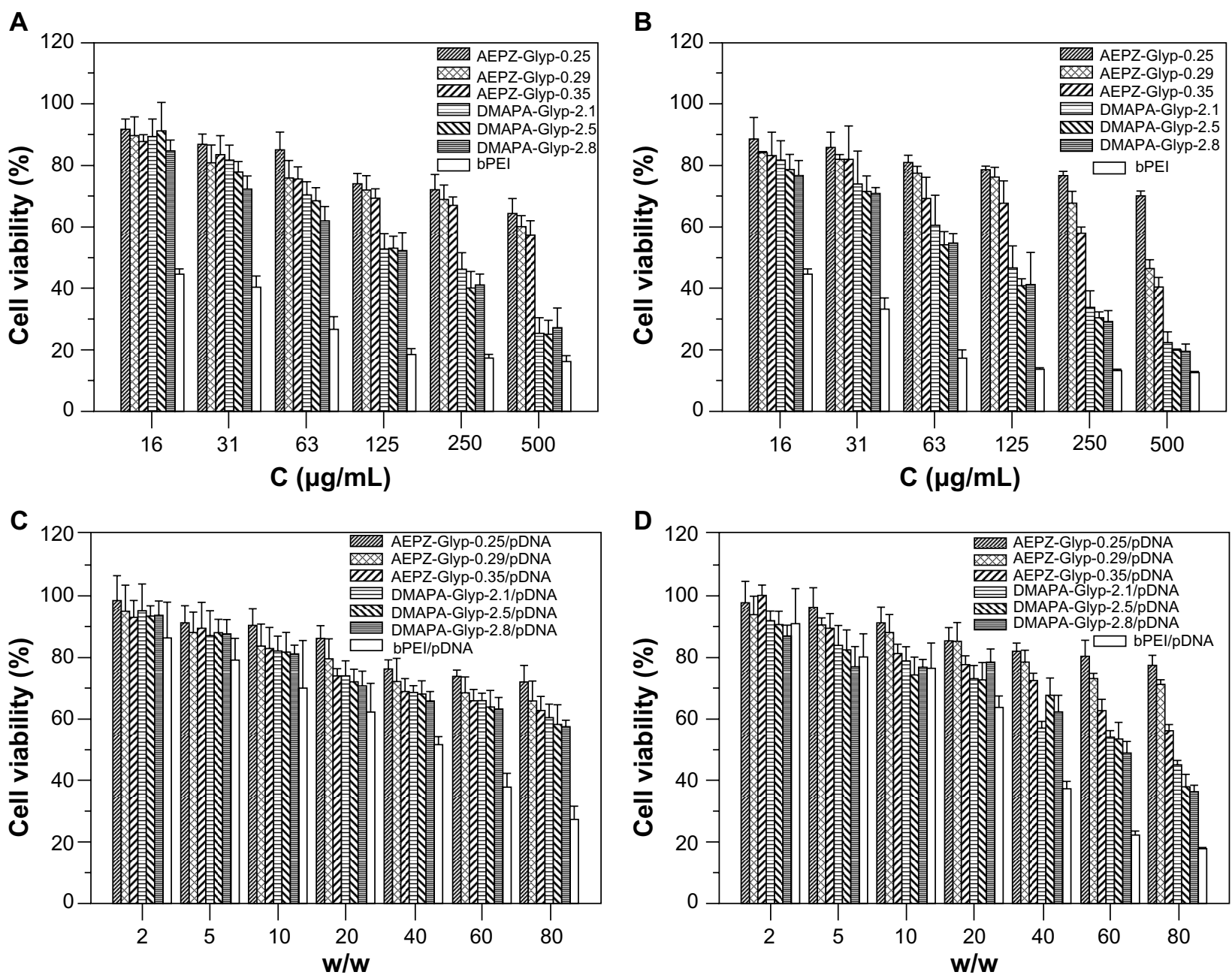

Figure 8 Viability of (A) 293 T cells and (B) CNE2 cells incubated with the glycogen derivatives and bPEl at various concentrations for 24 hours ( $\mathrm{n}=5$ ), and viability of (C) 293T cells and (D) CNE2 cells incubated with the glycogen derivative/pDNA and bPEI/pDNA complexes at various weight ratios for 24 hours ( $n=5$ ).

Abbreviations: bPEI, branched polyethyleneimine; pDNA, plasmid deoxyribonucleic acid; DMAPA, 3-(dimethylamino)-I-propylamine; AEPZ, I-(2-aminoethyl) piperazine; Glyp, glycogen.

confirming the in vivo safety of the DMAPA-Glyp derivatives $(\mathrm{n}=3)$. The GFP expression in the blood vessels of the brain was then evaluated by laser-scanning confocal microscopy. As shown in Figure 10B, it was observed that the nuclei were stained blue, and a majority of GFP was expressed in cells of the vascular wall around blood vessels. These results indicated that the pDNA could be safely delivered to the cells of the vascular wall around brain blood vessels of SD rats by the DMAPA-Glyp derivatives, and then expressed as GFP. However, the green fluorescence was hardly observed in cells of the vascular wall around blood vessels in the control group (Figure 10C), confirming that the fluorescence was not the result of autofluorescence in tissue.

Overall, the results of in vivo evaluations confirmed that the hyperbranched glycogen derivatives could transfect
pDNA efficiently and express as GFP in the blood vessels of the brains of SD rats. The mechanism of gene transfection may be explained based on the literature. ${ }^{32,33}$ The DMAPAGlyp derivatives could be able to bind and condense pDNA to form the positive complexes, and protect pDNA from degradation by nuclease. The complexes entered the endosomes through endocytosis, owing to the electrostatic attraction between the complexes and the cell membranes. With the proton-sponge effect, the complexes escaped from the endosomes. The pDNA was finally released inside the cytoplasm and expressed as GFP. Furthermore, hypoxia-ischemia could promote the opening of the blood-brain barrier tight junction and increase the permeability of the blood-brain barrier. ${ }^{34,35}$ Therefore, the mechanism of the expression of GFP may be due to two factors: electrostatic attraction and the improved permeability of the blood-brain barrier. 

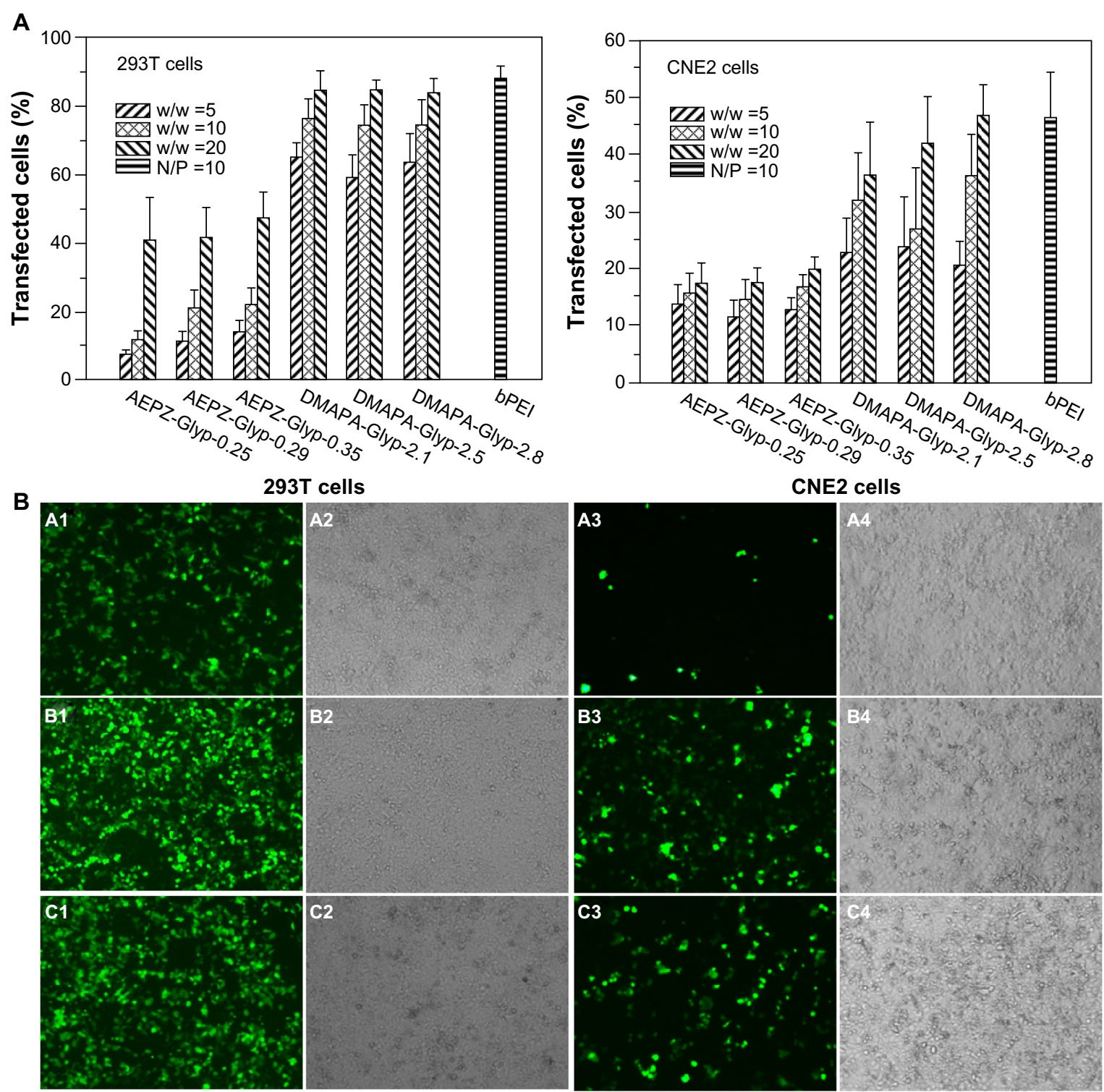

93T cells

Fluorescence

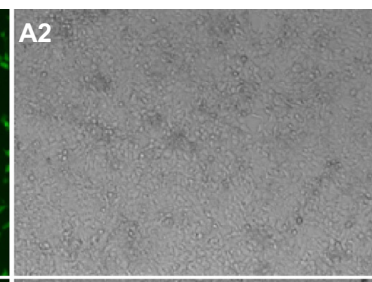

\section{CNE2 cells}

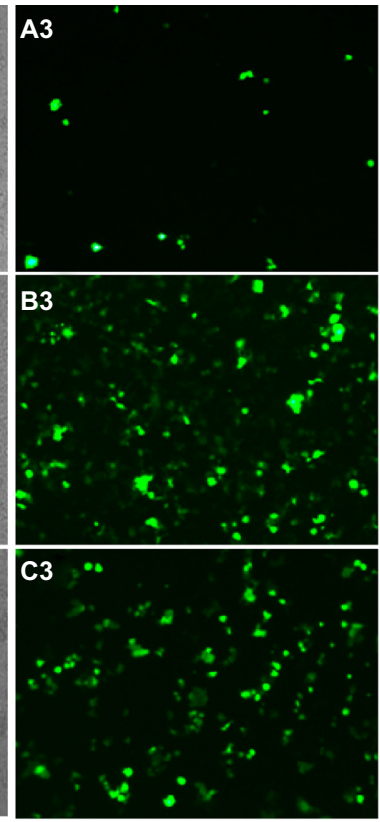

Fluorescence micrographs

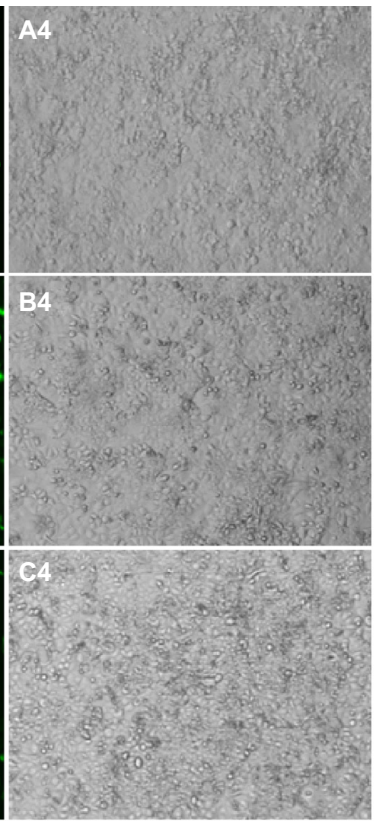

Light inverted micrographs

Figure 9 (A) Transfection efficiency of glycogen derivative/pDNA complexes at various weight ratios ( $w / w=5,10$, and 20) and the bPEl/pDNA complex (N/P =10) determined by flow cytometry in 293T cells and CNE2 cells $(n=3)$. (B) Fluorescence micrographs and light-inverted micrographs of $293 T$ cells and CNE2 cells transfected by the glycogen derivative/pDNA complexes (w/w =20): AEPZ-Glyp-0.35/pDNA (a), DMAPA-Glyp-2.8/pDNA (b), and bPEl/pDNA (N/P=10) ( $\times 100)(\mathbf{c})$.

Abbreviations: bPEI, branched polyethyleneimine; PDNA, plasmid deoxyribonucleic acid; N/P, N/P ratio refers to the ratio of moles of the amine groups of bPEI to moles of phosphates of pDNA; DMAPA, 3-(dimethylamino)-I-propylamine; AEPZ, I-(2-aminoethyl) piperazine; Glyp, glycogen.
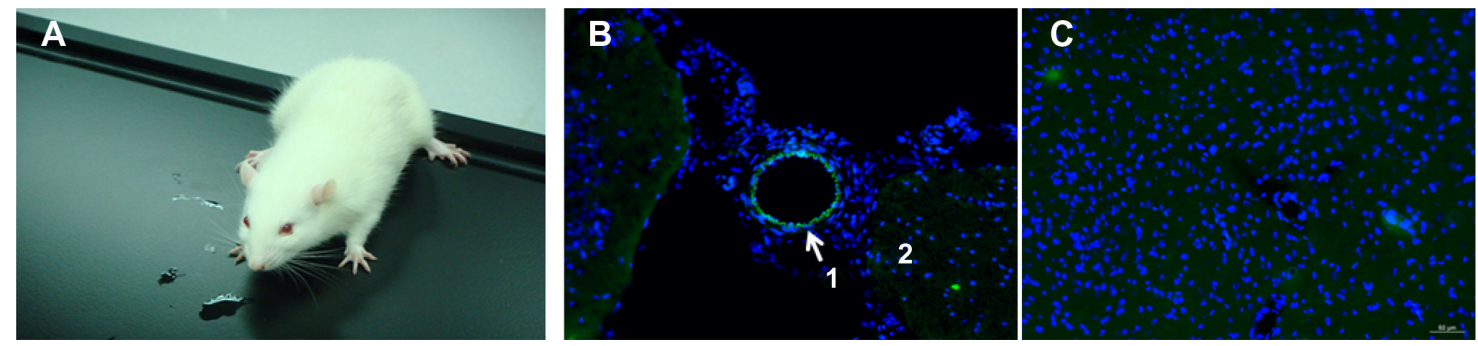

Figure 10 (A) A Sprague Dawley rat on the fifth day following injection of the DMAPA-Glyp-2.5/pDNA complex (w/w =20). (B and C) Laser-scanning confocal images of brain cryosections of the rat, stained by Hoechst $33342(\times 200)$. (B) The experimental group expressed green fluorescent protein (region I, cells of vascular wall; region 2 , cells of brain tissue); (C) the control group.

Abbreviations: DMAPA, 3-(dimethylamino)-I-propylamine; AEPZ, I-(2-aminoethyl) piperazine; Glyp, glycogen. 


\section{Conclusion}

A series of hyperbranched cationic glycogen derivatives conjugated with DMAPA and AEPZ oligoamine residues were synthesized, which exhibited better blood compatibility and lower cytotoxicity when compared to bPEI. They were able to bind and condense pDNA to form complexes of 100-250 nm in size. The transfection efficiency of the DMAPA-Glyp/pDNA complexes was higher than that of the AEPZ-Glyp/pDNA complexes in both the 293T and CNE2 cells, and almost equal to that of bPEI. The pDNA could be safely delivered to the blood vessels in the brains of SD rats with the MCAO model by the DMAPA-Glyp derivatives and then expressed as GFP. The DMAPA-Glyp derivatives are thus anticipated as a novel nonviral gene vector for future gene-therapy applications, such as in ischemic stroke.

\section{Acknowledgments}

This work was supported by the National Natural Science Foundation of the People's Republic of China (21244005, 20974130), and the Science and Technology Planning Project of Guangdong Province, People's Republic of China (2012B091100457).

\section{Disclosure}

The authors report no conflicts of interest in this work.

\section{References}

1. Selvam S, Thomas PB, Hamm-Alvarez SF, et al. Current status of gene delivery and gene therapy in lacrimal gland using viral vectors. Adv Drug Deliv Rev. 2006;58:1243-1257.

2. Varkouhi AK, Scholte M, Storm G, Haisma HJ. Endosomal escape pathways for delivery of biologicals. J Control Release. 2011;151: 220-228.

3. Toita S, Morimoto N, Akiyoshi K. Functional cycloamylose as a polysaccharide-based biomaterial: application in a gene delivery system. Biomacromolecules. 2010;11:397-401.

4. Wang R, Zhou L, Zhou Y, et al. Synthesis and gene delivery of poly(amido amine)s with different branched architecture. Biomacromolecules. 2010;11:489-495.

5. Malmo J, Varum KM, Strand SP. Effect of chitosan chain architecture on gene delivery: comparison of self-branched and linear chitosans. Biomacromolecules. 2011;12:721-729.

6. Fischer D, Harpe A, Kunath K, Petersen H, Li Y, Kissel T. Copolymers of ethylene imine and $\mathrm{N}$-(2-hydroxyethyl)-ethylene imine as tools to study effects of polymer structure on physicochemical and biological properties of DNA complexes. Bioconjug Chem. 2002;13: 1124-1133.

7. Schallon A, Jérome V, Walther A, Synatschke CV, Müller AHE, Freitag R. Performance of three PDMAEMA-based polycation architectures as gene delivery agents in comparison to linear and branched PEI. React Funct Polym. 2010;70:1-10.

8. Yamagata M, Kawano T, Shiba K, Mori T, Katayama Y, Niidome T. Structural advantage of dendritic poly(L-lysine) for gene delivery into cells. Bioorg Med Chem. 2007;15:526-532.

9. Zintchenko A, Philipp A, Dehshahri A, Wagner E. Simple modifications of branched PEI lead to highly efficient siRNA carriers with low toxicity. Bioconjug Chem. 2008;19:1448-1455.
10. Kim T, Seo HJ, Choi JS, et al. PAMAM-PEG-PAMAM: novel triblock copolymer as a biocompatible and efficient gene delivery carrier. Biomacromolecules. 2004;5:2487-2492.

11. Khan W, Hosseinkhani H, Ickowicz D, Hong PD, Yu DS, Domb AJ. Polysaccharide gene transfection agents. Acta Biomater. 2012;8: 4224-4232.

12. Jo J, Ikai T, Okazaki O, Yamamoto M, Hirano Y, Tabata Y. Expression profile of plasmid DNA by spermine derivatives of pullulan with different extents of spermine introduced. J Control Release. 2007;118: 389-398.

13. Nagasaki T, Hojo M, Uno A, et al. Long-term expression with a cationic polymer derived from a natural polysaccharide: schizophyllan. Bioconjug Chem. 2004;15:249-259.

14. Katav T, Liu L, Traitel T, Goldbart R, Wolfson M, Kost J. Modified pectin-based carrier for gene delivery: cellular barriers in gene delivery course. J Control Release. 2008;130:183-191.

15. Wang ZH, Li WB, Ma J, Tang GP, Yang WT, Xu FJ. Functionalized nonionic dextran backbones by atom transfer radical polymerization for efficient gene delivery. Macromolecules. 2011;4:230-239.

16. Deng J, Zhou Y, Xu B, Mai K, Deng Y, Zhang L. Dendronized chitosan derivative as a biocompatible gene delivery carrier. Biomacromolecules. 2011;12:642-649.

17. Song Y, Sun Y, Zhang X, Zhou J, Zhang L. Homogeneous quaternization of cellulose in $\mathrm{NaOH} /$ urea aqueous solutions as gene carriers. Biomacromolecules. 2008;9:2259-2264.

18. Zhou Y, Yang B, Ren X, et al. Hyperbranched cationic amylopectin derivatives for gene delivery. Biomaterials. 2012;33:4731-4740.

19. Putaux J, Potocki-Véronèse G, Remaud-Simeon M, Buleon A. Alpha-D-Glucan-based dendritic nanoparticles prepared by in vitro enzymatic chain extension of glycogen. Biomacromolecules. 2006;7: 1720-1728.

20. Rolland-Sabaté A, Mendez-Montealvo MG, Colonna P, Planchot V. Online determination of structural properties and observation of deviations from power law behavior. Biomacromolecules. 2008;9: 1719-1730.

21. Rolland-Sabaté A, Colonna P, Mendez-Montealvo MG, Planchot V. Branching features of amylopectins and glycogen determined by asymmetrical flow field flow fractionation coupled with multiangle laser light scattering. Biomacromolecules. 2007;8:2520-2532.

22. McArdle WD, Katch FI, Katch VL. Exercise Physiology: Energy, Nutrition, and Human Performance. Philadelphia: Lippincott Williams and Wilkins; 2006:12.

23. Gottlieb HE, Kotlyar V, Nudelman A. NMR chemical shifts of common laboratory solvents as trace impurities. J Org Chem. 1997;62: $7512-7515$.

24. Wu DC, Loh XJ, Wu YL, Lay CL, Liu Y. 'Living' controlled in situ gelling systems: thiol-disulfide exchange method toward tailor-made biodegradable hydrogels. J Am Chem Soc. 2010;132: 15140-15143.

25. Fischer D, Li Y, Ahlemeyer B, Krieglstein J, Kissel T. In vitro cytotoxicity testing of polycations: influence of polymer structure on cell viability and hemolysis. Biomaterials. 2003;24:1121-1131.

26. Liu Z, Li Z, Zhou H, Wei G, Song Y, Wang L. Imaging DNA molecules on mica surface by atomic force microscopy in air and in liquid. Microsc Res Tech. 2005;66:179-185.

27. Kainthan RK, Gnanamani M, Ganguli M, et al. Blood compatibility of novel water soluble hyperbranched polyglycerol-based multivalent cationic polymers and their interaction with DNA. Biomaterials. 2006;27: 5377-5390.

28. Yang J, Liu Y, Wang H, et al. The biocompatibility of fatty acid modified dextran-agmatine bioconjugate gene delivery vector. Biomaterials. 2012;33:604-613.

29. Lu B, Wang CF, Wu DQ, Li C, Zhang XZ, Zhuo RX. Chitosan based oligoamine polymers: synthesis, characterization, and gene delivery. $J$ Control Release. 2009;137:54-62.

30. Pack DW, Hoffman AS, Pun S, Stayton PS. Design and development of polymers for gene delivery. Nat Rev Drug Discov. 2005;4: 581-593. 
31. Liu YM, Reineke TM. Hydroxyl stereochemistry and amine number within poly(glycoamidoamine)s affect intracellular DNA delivery. J Am Chem Soc. 2005;127:3004-3015.

32. Xiong X, Uludağ H, Lavasanifar A. Biodegradable amphiphilic poly(ethylene oxide)-block-polyesters with grafted polyamines as supramolecular nanocarriers for efficient siRNA delivery. Biomaterials. 2009;30:242-253.

33. Lu W, Sun Q, Wan J, She Z, Jiang X. Cationic albumin-conjugated pegylated nanoparticles allow gene delivery into brain tumors via intravenous administration. Cancer Res. 2006;66:11878-11887.
34. Sandoval KE, Witt KA. Blood-brain barrier tight junction permeability and ischemic stroke. Neurobiol Dis. 2008;32:200-219.

35. Khan MM, Gandhi C, Chauhan N, et al. Alternatively-spliced extra domain A of fibronectin promotes acute inflammation and brain injury following cerebral ischemia in mice. Stroke. 2012;43:1376-1382. 


\section{Supplementary materials}
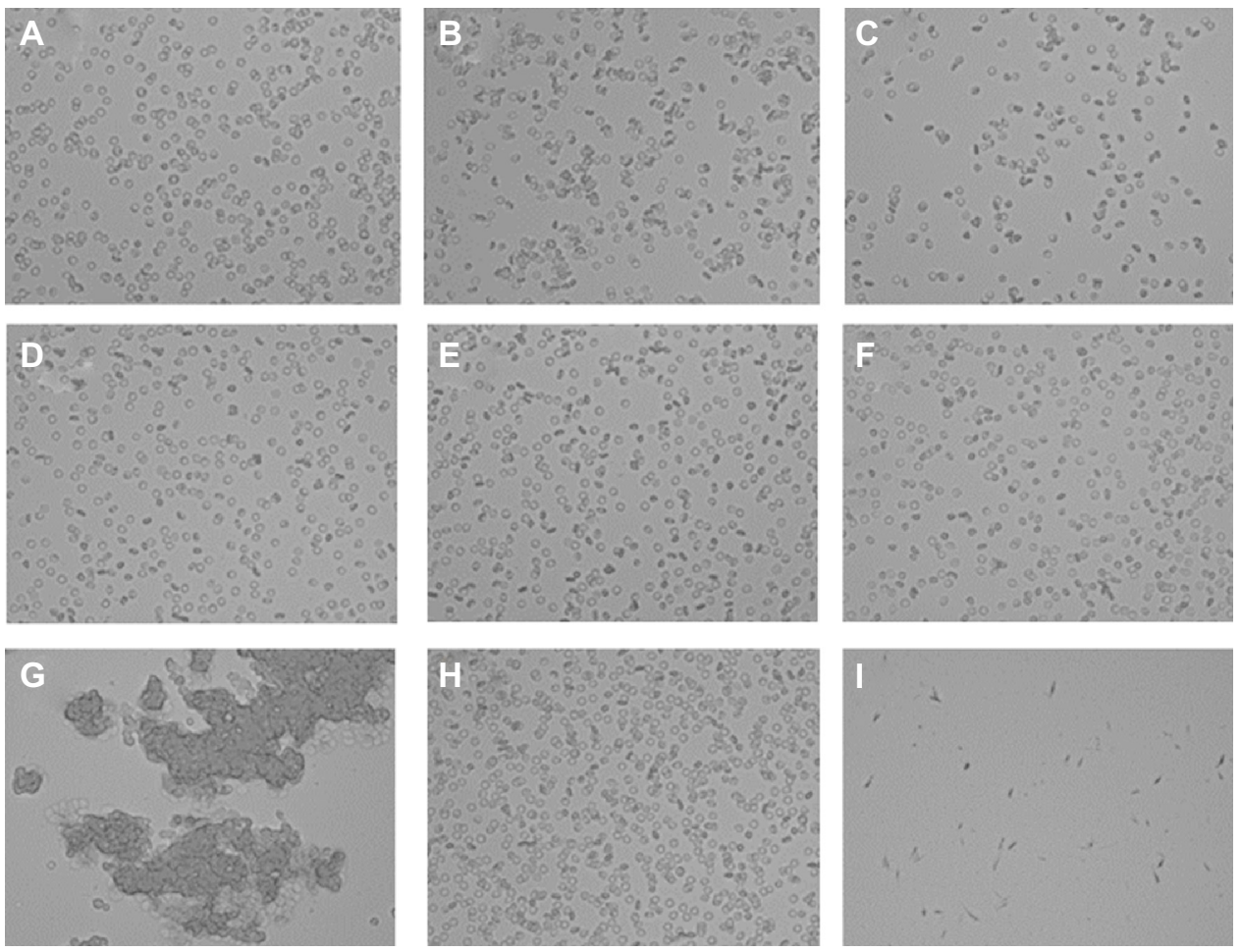

Figure SI Morphology of erythrocytes incubated with (A) AEPZ-Glyp-0.25, (B) AEPZ-Glyp-0.29, (C) AEPZ-Glyp-0.35, (D) DMAPA-Glyp-2.I, (E) DMAPA-Glyp-2.5, (F) DMAPA-Glyp-2.8, (G) bPEl, (H) $0.9 \% \mathrm{NaCl}$, and (I) $10 \%$ Triton X-100 ( $\times 400$, with a polymer concentration of $125 \mu \mathrm{g} / \mathrm{mL})$.

Abbreviations: bPEl, branched polyethyleneimine; DMAPA, 3-(dimethylamino)-I-propylamine; AEPZ, I-(2-aminoethyl) piperazine; Glyp, glycogen.
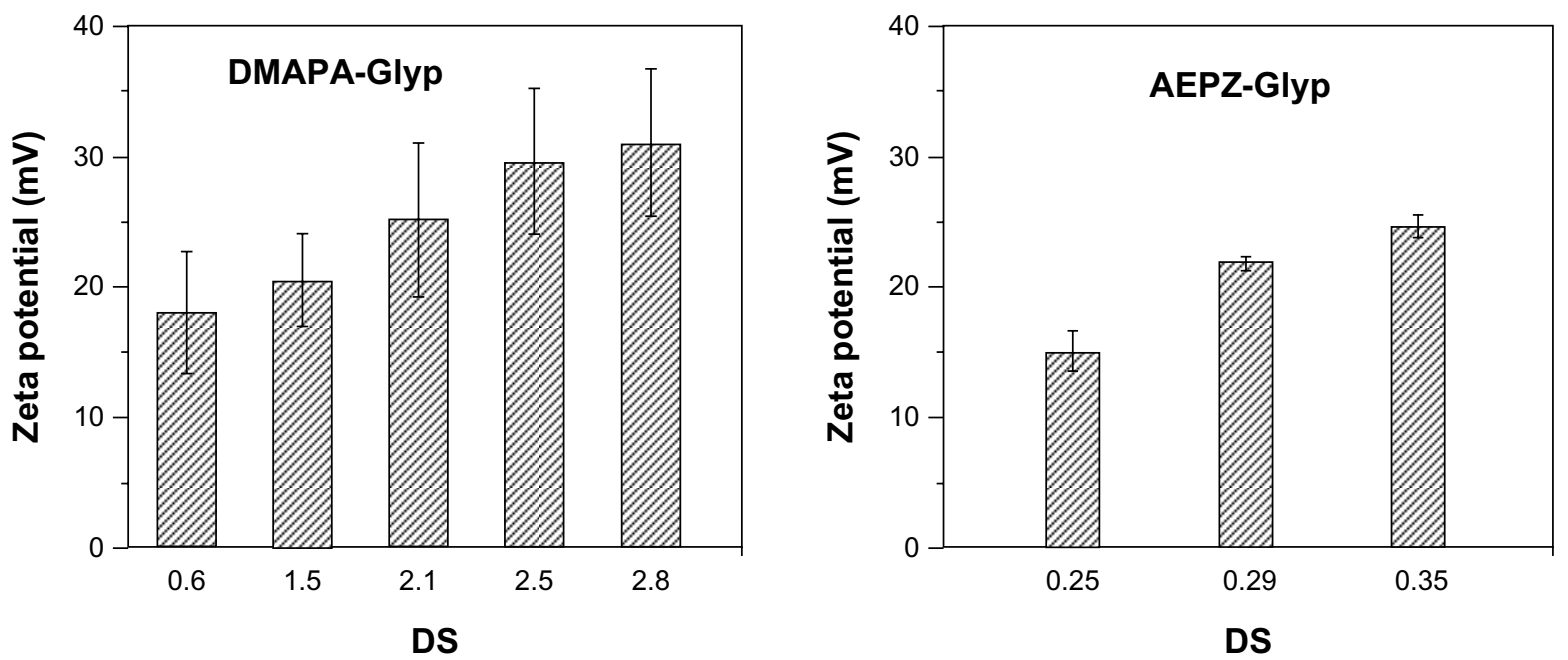

Figure S2 Zeta potentials of the cationic glycogen derivatives.

Abbreviations: DMAPA, 3-(dimethylamino)-I-propylamine; AEPZ, I-(2-aminoethyl) piperazine; Glyp, glycogen; DS, degree of substitution. 

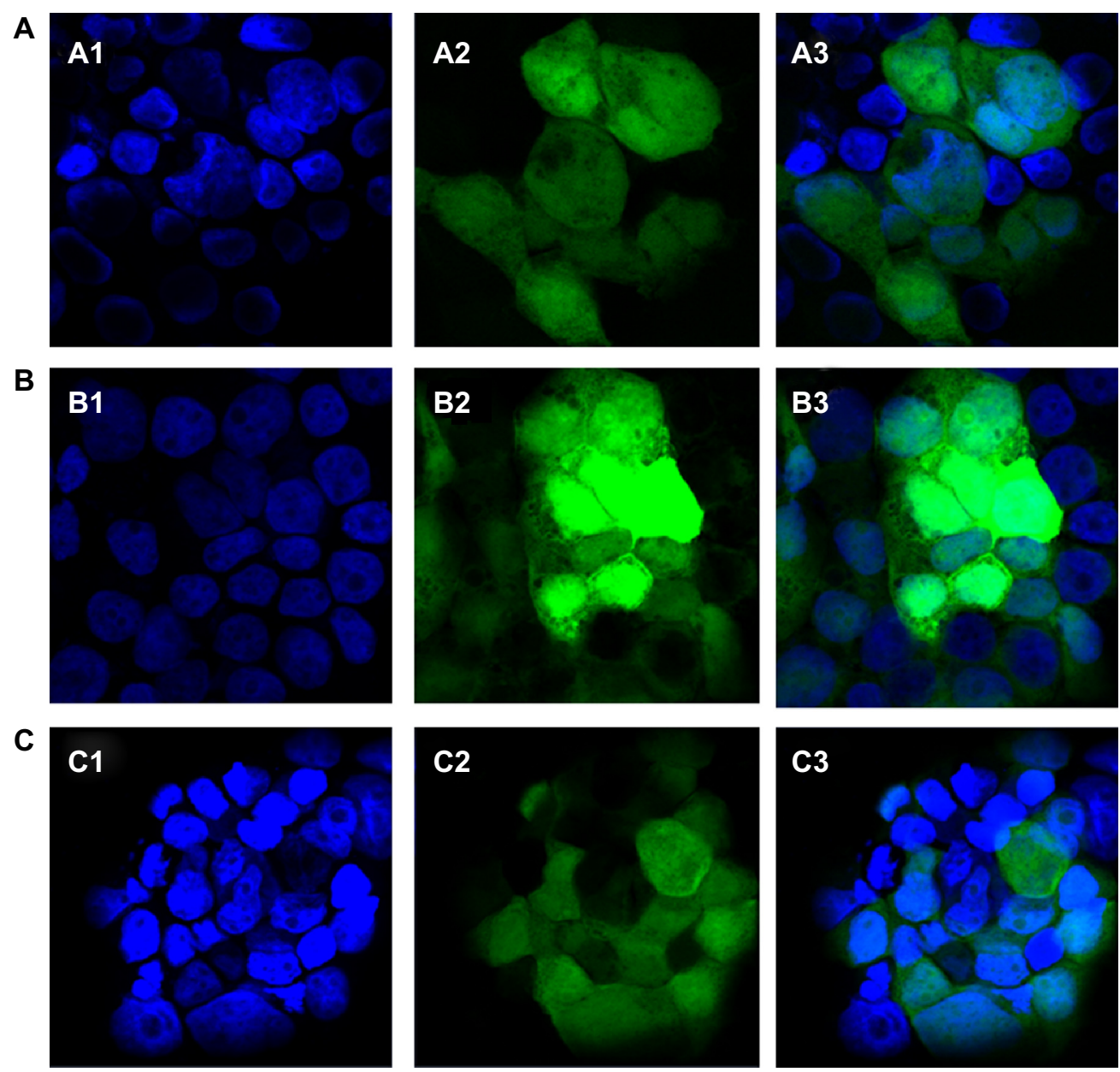

Figure S3 Laser-scanning confocal images of 293T cells transfected by the glycogen derivative/pDNA complexes (w/w =20): (A) AEPZ-Glyp-0.35/pDNA, (B) DMAPA-Glyp2.8/pDNA, and (C) bPEl/pDNA (N/P = 10). I, Nuclei stained by Hoechst 33342; 2, green fluorescent protein; 3, images I and 2 merged $(\times 400)$.

Abbreviations: bPEI, branched polyethyleneimine; PDNA, plasmid deoxyribonucleic acid; N/P, N/P ratio refers to the ratio of moles of the amine groups of bPEI to moles of phosphates of pDNA; DMAPA, 3-(dimethylamino)- I-propylamine; AEPZ, I-(2-aminoethyl) piperazine; Glyp, glycogen.

International Journal of Nanomedicine

\section{Publish your work in this journal}

The International Journal of Nanomedicine is an international, peerreviewed journal focusing on the application of nanotechnology in diagnostics, therapeutics, and drug delivery systems throughou the biomedical field. This journal is indexed on PubMed Central, MedLine, CAS, SciSearch ${ }^{\circledR}$, Current Contents ${ }^{\circledR} /$ Clinical Medicine,

\section{Dovepress}

Journal Citation Reports/Science Edition, EMBase, Scopus and the Elsevier Bibliographic databases. The manuscript management system is completely online and includes a very quick and fair peer-review system, which is all easy to use. Visit http://www.dovepress.com/ testimonials.php to read real quotes from published authors.

\footnotetext{
Submit your manuscript here: http://www.dovepress.com/international-journal-of-nanomedicine-journal
} 